\title{
Optimal Portfolio Construction: Application of Sharpe's Single-Index Model on Dhaka Stock Exchange
}

\author{
Imroz Mahmud *)
}

\begin{abstract}
This study aims to find whether Sharpe's single-index model of portfolio construction offers better investment alternatives to the investors of the Dhaka Stock Exchange (DSE). For this purpose, month-ended closing price data of 178 companies listed on the DSE, the prime bourse of Bangladesh, and the month-ended index value of DSEX have been used for the period starting from January 2013 to February 2018. The stocks selected for this study belong to 16 industrial sectors, and purposive sampling technique has been used to select these sectors. Sharpe's model formulates a unique cut-off rate and selects the stocks having an excess return-to-beta ratio above that rate. In this study, 54 stocks qualified to be a part of the optimal portfolio. Hence, the proportion of investment to be made on each of the stock is calculated according to the model. The study reveals that three industries occupy a hefty chunk $(65.78 \%)$ of the proposed investment portfolio. The constructed portfolio offers a monthly return of $2.1489 \%$ and carries $1.9516 \%$ risk as measured by standard deviation. The beta of the optimal portfolio is only 0.124003 . The constructed portfolio outperforms every individual stock as well as the market index in terms of offering the optimal riskreturn combinations. Therefore, this five-and-a-half-decade-old model offers a great opportunity for Bangladeshi investors to optimize return and diversify risk in an efficient manner.
\end{abstract}

Keywords: Single-Index Model; Sharpe; Optimal Portfolio; Dhaka Stock Exchange

\section{INTRODUCTION}

\subsection{Research Background}

The ground-breaking article published by Markowitz in 1952 marked the beginning of modern portfolio theory. His model is concerned with creating an optimal portfolio of assets by risk-averse investors. According to Markowitz (1952), a risk-averse investor should choose efficient portfolios. An efficient portfolio is one that maximizes return for a given level of risk or minimizes risk for a given level of return. Markowitz's pioneering article, named Portfolio Selection, and his subsequent studies have been a source of inspiration for many researchers and scholars. His model was intended to be pragmatic and implementable. However, it is ironic that the volume of work required to construct an optimal portfolio was staggering, and thus the model was rarely used in practice (Elton, Gruber, \& Padberg, 1976). To form a portfolio using Markowitz's model we will need $\mathrm{N} \times(\mathrm{N}-1) / 2$ correlation coefficients, where " $\mathrm{N}$ " stands for the number of stocks a firm or an investor follows (Elton, Gruber, Brown, \& Goetzmann, 2009). Consequently, the implementation of the model is also quite time consuming and expensive. Recognition of these problems has motivated researchers to develop and simplify the portfolio construction process. In quest of a solution, William F. Sharpe came up with a simplified alternative to the Markowitz's model that significantly reduces the data input and computational requirements.

The model developed by Sharpe, known as Sharpe single-index model, is based on the assumption that co-movement between stocks' return is due to movement in return of a broad market index (Sharpe, 1963). Such a return on a broad market index is taken as a valid substitution for the common macroeconomic factor (Bodie, Kane, \& Marcus, 2009). According to Sharpe's model, a single value, known as the cut-off rate, measures the desirability of including security in 
the optimal portfolio. The portfolio construction process is simplified if the cut-off rate can dictate which securities to include in our optimal portfolio, and which ones to exclude. This simplified model not only allows an investor to pick securities for his/her optimal portfolio but also helps determine how much to invest in each of those securities (Elton, Gruber, \& Padberg, 1976). Hence, this five-and-a-half-decade-old model is still considered as one of the simplest and most widely used models for portfolio construction.

Dhaka Stock Exchange (DSE), formerly known as East Pakistan Stock Exchange Association Ltd. (1954-1962) and East Pakistan Stock Exchange Ltd. (1962-1964), began its journey long before the independence of Bangladesh with a paid-up capital of about BDT 4 billion (Dhaka Stock Exchange, 2017). The introduction of DSE has opened the door to many investors and businesses in fulfilling their investment and financing needs. However, DSE evolved slowly and could not properly fulfill these needs due to various political unrest, corruption, military coups and other massive anomalies (Rahaman, Hasan, \& Ahsan, 2013). These evils have always haunted the capital market of Bangladesh that resulted in some turmoils in 1990, 1996, 2011 and 2012 for instance. As a result, investors' trust and confidence in DSE have plummeted. Unless we make the necessary changes to this situation, the capital market can't contribute in a desirable way to the economic growth of Bangladesh. These present a great challenge for the rational investors of Bangladesh in picking a good investment, which necessitates the adoption of a systematic approach in the investment decision. A sound and in-depth knowledge of portfolio analysis can help them to diversify the investment risk without unfavorably affecting the return.

The present study has been carried out with a view to evaluating how well the portfolio constructed using Sharpe's single-index model performs in the Bangladeshi capital market. Besides, the study aims to assist both domestic and foreign investors of DSE in simplifying the construction of an optimal portfolio of equity securities. Although there have been extensive studies on this regard in the developed economies, empirical work on simplifying the portfolio construction and evaluation of its performance is comparatively scarce in the developing economies. Specifically, in Bangladesh, there is a significant lacuna of research in this context. Besides, none of the studies carried out in the developing economies consisted of a wide-ranging collection of stocks representing various industrial sectors. As a result, these studies cannot completely reveal the portfolio optimization potential of Sharpe's model.

\subsection{Research Problem}

a) Does Sharpe's model of portfolio construction offer better risk-return combination to the investors of DSE?

b) Does the portfolio construction model propounded by Sharpe simplify the investment decision for the investors of DSE?

\subsection{Research Purpose}

The primary objective of this study is to find whether Sharpe's single-index model of portfolio construction offers better investment options to the investors of DSE.

\section{THEORETICAL FRAMEWORK}

Before Markowitz's monumental work on portfolio selection, investors concentrated on evaluating the risk and return characteristics of individual stocks in constructing their portfolios. The rule of thumb was to pick a stock that offered the best opportunity of earning reward with the least amount of risk (Paudel \& Koirala, 2007). Markowitz revolutionized the investment criteria by 
suggesting three statistics: mean, standard deviation, and correlation with other stocks for selecting the best portfolio at any given level of risk.

The theoretically sophisticated and conceptually comprehensive model of Markowitz has a severe drawback: the volume of work required to form a portfolio using this model is staggering and beyond the capacity of all but a few specialists. A lot of researchers tried to simplify the portfolio construction process and finally, William F. Sharpe came up with a solution in 1963 that is known as Sharpe's single-index model.

Skarica \& Zrinka (2012) stated that the classical Markowitz's model often been criticized because of useless and impractical as they are not structured to apply a mean-variance optimization approach. Elton, Gruber, \& Padberg $(1976,1977,1978)$ applied a variety of models, such as singleindex, multi-index, and constant correlation models, to establish simple criteria for optimal portfolio selection. According to their findings, they have suggested using the single-index model for its simplicity and efficiency. The model was also recommended to apply to a large population of securities as it serves as a simplified alternative to the classical mean-variance approach of portfolio optimization (Haugen, 1993). Paudel \& Koirala (2007) conducted a study on the application and comparison of Markowitz and Sharpe's model and advised using either of the models for optimizing portfolio performance. However, the findings of Briec \& Kerstens (2009) portrays a contrasting picture. They suggested using Markowitz's model for long-term investments and argued that a single-index model is not suitable for investment portfolios having multi-period durations. To form efficient portfolios using the Markowitz model, clustering of high dimensional stock data was found to be more effectual (Nanda, Mahanty, \& Tiwari, 2010). By clustering stocks, the problem of efficient frontier can be solved more efficiently, which results in enhanced diversification.

According to Frankfurter, Phillips, \& Seagle (1976), the single-index model is just a simplified variation to the Markowitz's model, and it is based on the assumption that co-movement between stocks' return is due to movement in market return, or return of a broad market index to be specific. As per their study, both models produced identical results under conditions of certainty. However, in conditions of uncertainty, the single-index model produced superior results than Markowitz's model. Nevertheless, when a short span of historical data is used, the single-index model performed worse than Markowitz's model. The findings of Omet (1995) is also consistent with the previous studies. He stated that both models yield similar outcomes, but emphasized using the single-index model, as it is more pragmatic in generating the efficient frontier.

Rani \& Bahl (2012) used Sharpe's model for portfolio construction with and without the procedure of short sales on 30 stocks selected from BSE (Bombay Stock Exchange). Both of their portfolios were efficient as they offered the best risk-return combinations possible. But the portfolio prohibiting short sales performed a tad bit better than the one allowing it. Sen \& Fattawat (2014) also attempted to construct portfolios from 30 stocks, listed on BSE, using both Markowitz and Sharpe's model. Their study revealed that Sharpe's model outperformed its predecessor in risk reduction. In another study, Singh \& Gautam (2014) and Ahuja (2017) formed an optimal portfolio of stocks selected from the banking sector of NSE (National Stock Exchange, Mumbai) and BSE (Bombay Stock Exchange). They also suggested Sharpe's model for its simplicity and efficacy.

From the literature reviewed, we could easily conclude that most of the studies were conducted in the developed economies. Only a few studies were carried out in the developing ones. Specifically, in Bangladesh, there exists a lacuna of research regarding this context. Besides, none of the studies conducted in developing economies were extensive. 


\subsection{Sharpe's Single-Index Model}

William Sharpe (1963) simplified variant of the Markowitz Model, universally known as the Sharpe's single-index model, assumes that the co-movement between stocks' return is due to movement in return of a broad market index, which is DSEX in our case. Hence, the primary equation underlying the single-index model is:

$$
R_{i}=\alpha_{i}+\beta_{i} R_{m}+\varepsilon_{i}
$$

Where, $R_{i}=$ Expected return on security $\mathrm{i}, \alpha_{i}=$ Intercept of the straight line or alpha coefficient (Constant), $\beta_{i}=$ Slope of a straight line or beta coefficient, $R_{m}=$ The rate of return on market index, and $\varepsilon_{i}=$ Error term.

Alpha co-efficient $\left(\alpha_{i}\right)$ and error term $\left(\varepsilon_{i}\right)$ are two components of a random variable denoted by $a_{i}$. Since the error term $\left(\varepsilon_{i}\right)$ has an expected value of zero, therefore the mean return on security can be expressed as:

$$
\bar{R}_{i}=\alpha_{i}+\beta_{i} \bar{R}_{m}
$$

To perform the portfolio optimization, the measurement of spread and co-movement of return statistics is also required. The mathematical equations required regarding this respect are:

$$
\sigma_{i}^{2}=\beta_{i}^{2} \sigma_{m}^{2}+\sigma_{e i}^{2}
$$

Where, $\sigma_{i}^{2}=$ Total variance of a security's return, $\beta_{i}^{2} \sigma_{m}^{2}=$ Market-related variance, $\sigma_{e i}^{2}=$ Variance of a stock's movement that is not associated with the movement of the market index, i.e. the stock's unsystematic risk.

$$
\sigma_{i j}=\beta_{i} \beta_{j} \sigma_{m}^{2}
$$

Where, $\sigma_{i j}=$ The covariance of returns between securities $\mathrm{i}$ and $\mathrm{j}, \beta_{i}=$ Beta of security $\mathrm{i}$, $\beta_{j}=$ Beta of security $\mathrm{j}$, and $\sigma_{m}^{2}=$ Variance of market return.

The monthly return of the selected securities is calculated using the following equation.

$$
R_{i t}=\frac{P_{i t}}{P_{i t-1}}-1
$$

Where, $\mathrm{R}_{\mathrm{it}}=$ Monthly return on stock $\mathrm{i}$ at time $\mathrm{t}, \mathrm{P}_{\mathrm{it}}=$ Monthly closing price of the stock $\mathrm{i}$ at time $\mathrm{t}$, and $\mathrm{P}_{\mathrm{it}-1}=$ Monthly closing price of the stock $\mathrm{i}$ at time $\mathrm{t}-1$.

In the same manner, the return characteristics of the benchmark market index (DSEX) is calculated using the following equation.

$$
R_{m t}=\frac{I_{i t}}{I_{i t-1}}-1
$$

Where, $\mathrm{R}_{\mathrm{mt}}=$ Monthly return on the market index at time $\mathrm{t}, \mathrm{I}_{\mathrm{it}}=$ Monthly closing market index value at time $\mathrm{t}$, and $\mathrm{I}_{\mathrm{it}-1}=$ Monthly closing market index value at time $\mathrm{t}-1$.

The excess return yielded by risky security is calculated by subtracting the risk-free rate of return, which is 0.4784 percent per month (or 5.74 percent per annum) in our case, from the expected return of that risky security. The sensitivity of security's return to the movement in the market's return, popularly known as systematic risk or beta coefficient, is required for analyzing the risk of a security. The beta coefficient can be calculated as follows:

$$
\beta_{i}=\frac{\sigma_{i m}}{\sigma_{m}^{2}}
$$


Where, $\sigma_{i m}=$ Covariance of the stock i return with the market return, and $\sigma_{m}^{2}=$ Variance of the market return.

Based on the equations depicted above, it is just a matter of a few steps to reach our optimal portfolio. Sharpe's single-index model greatly simplifies the portfolio construction process by taking a single number to quantify the desirability of a stock's inclusion in the optimal portfolio. If one is ready to accept the standard form the single-index model as describing the co-movement between securities, such a number exists. In this instance, the desirability of any stock is directly related to the excess return to the Beta ratio (Elton, Gruber, Brown, \& Goetzmann, 2009):

$$
\frac{\bar{R}_{i}-R_{f}}{\beta_{i}}
$$

Where, $\bar{R}_{i}=$ Expected return on stock $i, R_{f}=$ Return on a riskless asset, and $\beta_{i}=$ Expected change in the rate of return on stock $i$ associated with a $1 \%$ change in the market return. The excess return to Beta ratio measures the additional return on security for each unit of systematic risk or non-diversifiable risk. In a colloquial manner, this ratio expresses the relationship between the potential risk and reward.

Once we have the excess return to the Beta ratio for each of the stocks under consideration, the following step is to rank those stocks in descending order of their respective ratios. Since we are assuming that short selling is prohibited, any stock with a negative excess return to Beta ratio has been excluded from further analyses.

The stocks to be included in the optimal portfolio depend on an unprecedented cutoff rate such that all stocks with higher ratios of $\left(\bar{R}_{i}-R_{f}\right) / \beta i$ are included and all stocks with lower ratios are excluded. This cut-off point is indicated by $C^{*}$, and is computed from the characteristics of all the stocks that belong to the optimal portfolio. To determine $\mathrm{C}^{*}$, it is required to estimate its value as if there were different numbers of stocks in the optimal portfolio. If we nominate $C_{i}$ as a candidate for $\mathrm{C}^{*}$. The value of $C_{i}$ is calculated when $i$ securities are assumed to belong to the optimal portfolio. For a portfolio of $i$ stocks, $C_{i}$ is given by:

$$
C_{i}=\frac{\sigma_{m}^{2} \sum_{j=1}^{i} \frac{\left(\bar{R}_{j}-R_{f}\right) \beta_{j}}{\sigma_{e j}^{2}}}{1+\sigma_{m}^{2} \sum_{j=1}^{i} \frac{\beta_{j}^{2}}{\sigma_{e j}^{2}}}
$$

Where, $\sigma_{m}^{2}=$ The variance in the market index, and $\sigma_{e j}^{2}=$ The variance of a stock's movement that is not associated with the movement of the market index. This is commonly referred to as a stock's unsystematic risk. After estimating the $C_{i}$ of all the stocks, the highest $C_{i}$ value is selected as the cut-off point $\left(C^{*}\right)$, which is then compared with the excess return to the Beta ratio of each stock. All stocks used in the calculation of $C_{i}$ have an excess return to Beta above $C_{i}$ and all stocks not used to calculate $C_{i}$ have an excess return to Beta below $C_{i}$. There will always be one and only one $C_{i}$ with this property and it is the cut-off point, $\mathrm{C}^{*}$.

After determining which stocks to be included in the optimal portfolio, the investors must find out the optimum percentage of capital to be invested in each of them. The percentage invested in each stock is:

$$
X_{i}=\frac{Z_{i}}{\sum_{j=1}^{N} Z_{j}}
$$

Where $Z_{i}=\frac{\beta_{i}}{\sigma_{e i}^{2}}\left(\frac{\bar{R}_{i}-R_{f}}{\beta_{i}}-C^{*}\right)$ 
The former expression indicates the weights on each stock, and they sum up to one. The latter expression determines the relative investment in each stock. The residual variance on each security $\sigma_{e i}^{2}$ plays a vital role in determining the amount to be invested in each security.

After determining the weights on each security, beta and alpha on a portfolio are estimated to find out the portfolio risk and return. Beta on a portfolio, $\beta_{p}$, is a weighted average of the individual $\beta_{i}$ on each stock in the portfolio and is denoted by:

$$
\beta_{p}=\sum_{i=1}^{n} X_{i} \beta_{i}
$$

Similarly, the Alpha on the portfolio, $\alpha_{p}$, is calculated as:

$$
\alpha_{p}=\sum_{i=1}^{n} X_{i} \alpha_{i}
$$

The return on the investor's portfolio can be expressed as:

$$
\bar{R}_{p}=\alpha_{p}+\beta_{p} \bar{R}_{m}
$$

Finally the risk of the investor's portfolio, $\sigma_{p}$, as:

$$
\left.\sigma_{p}=\sqrt{\left(\beta_{p}^{2}\right.} \sigma_{m}^{2}+\sum_{i=1}^{N} X_{i}^{2} \sigma_{e i}^{2}\right)
$$

All the equations (eq. 1-15) cited above are sourced from the book of Elton, Gruber, Brown, \& Goetzmann (2009).

\section{RESEARCH METHOD}

\subsection{Research Design}

In the pursuit of constructing an optimal portfolio of equity securities traded on DSE, monthly closing price and benchmark market index (DSEX) data have been used for the period starting from January 2013 to February 2018. The secondary data used in this study are collected from DSE Library.

\subsection{Population and Sample}

The study was initially aimed at all, 228 to be specific, the "A" category companies offering equity securities that belong to sixteen industrial sectors. The industries covered in this study are listed in Table 1. Purposive sampling technique has been applied to select these industrial sectors. The companies which are regular at holding annual general meetings and have declared a dividend at the rate of ten percent or above in the last calendar year are classified as "A" category companies (Dhaka Stock Exchange, 2018). Due to the unavailability of data during the aboved study period, 50 companies have been excluded from the portfolio construction, which leads to a final sample size of 178 companies. The average monthly cutoff yield of 91-day Treasury Bill has been used as a proxy for the risk-free rate of return (Bangladesh Bank, n.d.).

The 178 sample companies selected following the above-mentioned criteria constitutes 61.59 percent of all the equity securities (289) from the sixteen industrial sectors (refer to Table 1). A number of statistical techniques have been applied to analyze the risk-return characteristics and to construct the optimal portfolio of equity securities using Microsoft Excel 2016. In addition to substantial data coverage, the study covers a period of five years and two months, which reduces the possibility of sampling error and the influence of temporary fluctuations to distort the study outcome. Hence, the sample size can be assumed as adequate to represent the population and make smart investment decisions. 
Table 1 Sector-wise Representation of Sample Stocks

\begin{tabular}{|c|c|c|c|c|c|}
\hline \multicolumn{2}{|c|}{ Name of the Industry/Sector } & $\begin{array}{c}\text { Total } \\
\text { Number of } \\
\text { Companies }\end{array}$ & $\begin{array}{l}\text { Number of } \\
\text { Category-A } \\
\text { Companies } \\
\end{array}$ & $\begin{array}{c}\text { Sample } \\
\text { Companies }\end{array}$ & $\begin{array}{c}\text { Data } \\
\text { Coverage } \\
(\%) \\
\end{array}$ \\
\hline \multicolumn{2}{|l|}{ Banks } & 30 & 29 & 29 & $96.67 \%$ \\
\hline \multicolumn{2}{|l|}{ Financial Institutions } & 20 & 12 & 12 & $60.00 \%$ \\
\hline \multicolumn{2}{|l|}{ Engineering } & 36 & 29 & 17 & $47.22 \%$ \\
\hline \multicolumn{2}{|l|}{ Food \& Allied } & 18 & 9 & 8 & $44.44 \%$ \\
\hline \multicolumn{2}{|l|}{ Fuel \& Power } & 19 & 16 & 13 & $68.42 \%$ \\
\hline \multicolumn{2}{|l|}{ Jute } & 3 & 2 & 2 & $66.67 \%$ \\
\hline \multicolumn{2}{|l|}{ Textile } & 49 & 35 & 18 & $36.73 \%$ \\
\hline \multicolumn{2}{|l|}{ Pharmaceuticals \& Chemicals } & 28 & 24 & 16 & $57.14 \%$ \\
\hline \multicolumn{2}{|l|}{ Service \& Real Estate } & 7 & 6 & 3 & $42.86 \%$ \\
\hline \multicolumn{2}{|l|}{ Cement } & 7 & 6 & 5 & $71.43 \%$ \\
\hline \multicolumn{2}{|l|}{ IT Sector } & 8 & 7 & 5 & $62.50 \%$ \\
\hline \multicolumn{2}{|l|}{ Tannery Industries } & 6 & 5 & 4 & $66.67 \%$ \\
\hline \multicolumn{2}{|l|}{ Ceramics Sector } & 5 & 3 & 3 & $60.00 \%$ \\
\hline \multicolumn{2}{|l|}{ Insurance } & 47 & 42 & 41 & $87.23 \%$ \\
\hline \multicolumn{2}{|l|}{ Telecommunication } & 2 & 2 & 1 & $50.00 \%$ \\
\hline \multirow{2}{*}{\multicolumn{2}{|c|}{ Travel \& Leisure }} & 4 & 1 & 1 & $25.00 \%$ \\
\hline & & 289 & 228 & 178 & $61.59 \%$ \\
\hline \multicolumn{6}{|c|}{ Source: Secondary Data Processed, 2018} \\
\hline Dhaka Stock Exchange & \multicolumn{2}{|c|}{$\begin{array}{c}\text { Sharpe's Single-Index } \\
\text { Model }\end{array}$} & & \multicolumn{2}{|c|}{$\begin{array}{l}\text { Optimal Portfolio } \\
\text { Investment }\end{array}$} \\
\hline
\end{tabular}

Picture 1 Research Framework

\section{RESEARCH RESULT AND ANALYSIS}

\subsection{Descriptive Analysis}

Risk and return have always been the decisive factors in any investment model, and Sharpe's single-index model is of no exception. To apply this model, expected return and risk of each instrument are required. Thus, the month-ended closing price data of the 178 sample stocks as well as the month-ended index value of DSEX, for the period ranging from January 2013 to February 2018, have been used to estimate various risk and return characteristics. The mean monthly return and risk in terms of standard deviation, variance, covariance with market return, and the beta coefficient for each of the selected stocks have been calculated and depicted in Appendix-A.

The risk-return combinations offered by each of the 178 selected stocks have been portrayed in Picture-1. Analysis of the return data on the vertical axis reveals that most of the stocks yielded a monthly return from -0.27 percent to 1.3 percent. However, the average risk carried by the stocks is about 11.5 percent (Picture 1). Although Picture 1 paints an overall picture of the risk and returns 
composition offered by the stocks, we cannot pinpoint any precise information from it. An in-depth examination of the data in Appendix-A can be quite useful in this regard.

As revealed by Appendix A, the stock of Northern Jute Manufacturing Co. Ltd. yields the highest monthly return (8.227 percent) followed by Desh Garments Ltd. (5.439 percent) and Renwick Jajneswar \& Co (Bd) Ltd. (4.892 percent). In terms of risk, the stock of Legacy Footwear Ltd. has the highest standard deviation (29.845 percent) followed by Grameenphone Ltd. (27.499 percent) and Northern Jute Manufacturing Co. Ltd. (26.969 percent). It is also found that 114 stocks offered a return below the market rate, which is 0.681 percent in our study, and surprisingly none of the stocks in this study had a beta value above the market.

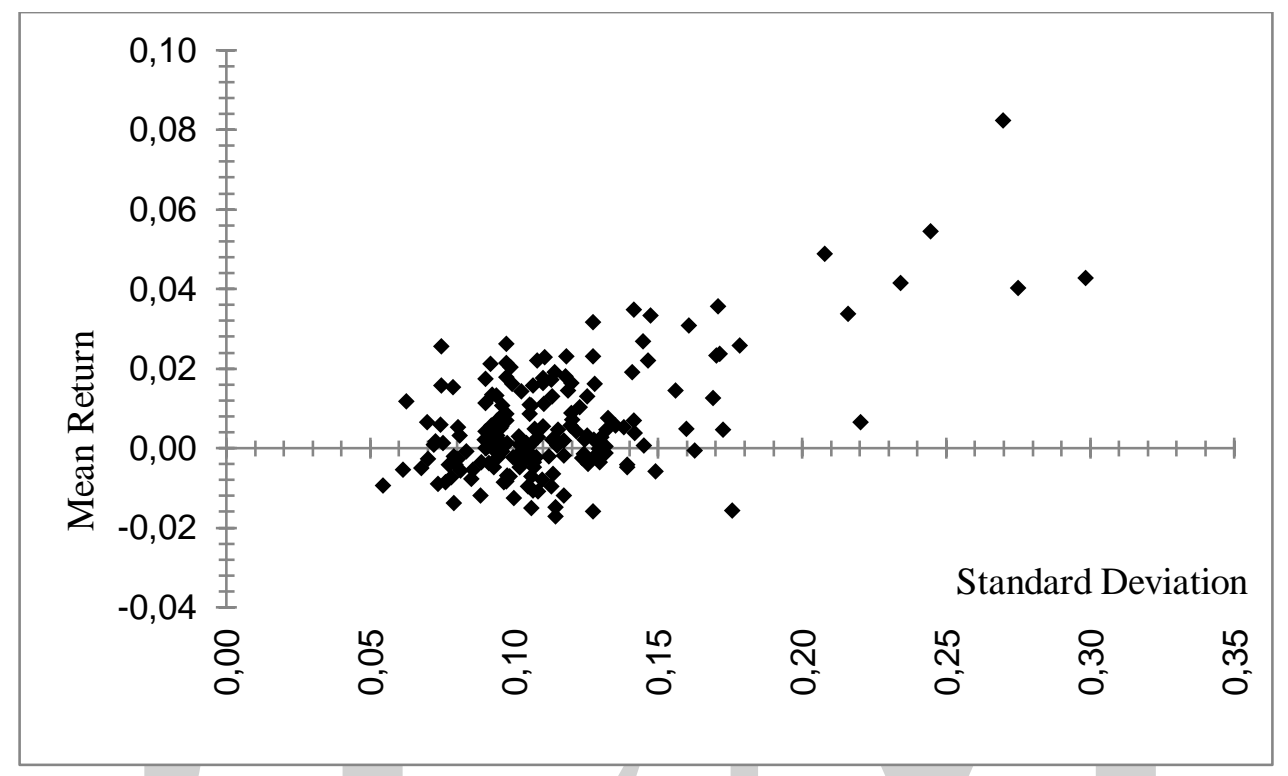

Picture 2 Risk-Return Combination of Each Stock (Secondary Data Processed, 2018)

According to Sharpe's single-index model, the expected return $\left(\bar{R}_{i}\right)$ has two components: a unique or firm-specific part $\left(\alpha_{i}\right)$ and a market-related part $\left(\beta_{i} \bar{R}_{m}\right)$. Likewise, a security's variance $\left(\sigma_{i}^{2}\right)$ has the same two components: a unique risk $\left(\sigma_{e i}^{2}\right)$ and a market-related risk $\left(\beta_{i}^{2} \sigma_{m}^{2}\right)$. The stocks having larger beta value also have a greater part of return that is dependent on the market's performance. Breakdowns of risk \& return will guide us to glean some idea about how much this model is going to benefit the investors in their quest for optimizing risk and return. Besides, these variables will be used in further calculations related to portfolio construction and performance evaluation. Hence, the decomposition of each firm's return and risk into unique and market-related parts are presented in Appendix-B.

By analyzing the decomposition of return, we can infer that the contribution of a stocks independent component is the dominant factor than its market-related component. Similarly, the breakdown of risk leads us to the identical conclusion: the contribution of a security's unsystematic variance in its total variance is the dominant factor than its systematic variance. The result suggests that the stocks selected for this study offer a significant opportunity for reduction of unsystematic risk, which we will be able to verify when we construct the optimal portfolio and measure its performance.

Sharpe's model provided a simple criterion, called the excess return-to-beta ratio, to quantify the desirability of a stock's inclusion in the optimal portfolio. Therefore, the excess return-to-beta 
ratio for each stock has been calculated and the stocks are ranked in descending order according to their respective ratios (Appendix-C). The mean monthly cutoff yield of 91-day Treasury Bill, which is 0.4784 percent, has been used as a proxy for the risk-free rate of return. Of the 178 stocks studied, only 70 stocks have a positive excess return-to-beta ratio. Since short selling is assumed to be prohibited, the rest of the stocks have been excluded from further analysis.

Among the stocks studied, Renwick Jajneswar \& Co (Bd) Ltd. secured the top spot with an excess return-to-beta ratio of 6.18333. Legacy Footwear Ltd. and Grameenphone Ltd. were in the second and third spot with the respective ratio of 4.21675 and 1.12589 (Appendix-C). Among the top scorers, only Renwick Jajneswar \& Co (Bd) Ltd. secured the third position in terms of highest return generation. These outcomes suggest that the significantly lower beta value of Legacy Footwear Ltd. and Grameenphone Ltd. is the reason why these companies made their way to the top of the chart in terms of the excess return-to-beta ratio.

\subsection{Validity and Reliability}

This study only used secondary data from DSEX to defined the optimal investment portfolio proposed model, therefore, the validity and reliability test is not needed in this study.

\subsection{Research Analysis}

According to the single-index model, the selection of stock in the optimal portfolio depends on a unique cut-off rate $\left(C^{*}\right)$ and its comparison with the excess return-to-beta ratio of each stock studied. All stocks used for the estimation of $C^{*}$ have an excess return-to-beta ratio above the cut-off rate and the stocks excluded from the estimation have an excess return-to-beta ratio below that rate. The detailed calculation of the cut-off rate is portrayed in Table 2.

Table 2 Calculation of The Cut-Off Rate

\begin{tabular}{|c|c|c|c|c|c|c|c|}
\hline Rank & Stock No. & $\frac{\bar{R}_{j}-R_{f}}{\beta_{j}}$ & $\frac{\left(\bar{R}_{j}-R_{f}\right) \beta_{j}}{\sigma_{e j}^{2}}$ & $\sum_{j=1}^{i} \frac{\left(\bar{R}_{j}-R_{f}\right) \beta_{j}}{\sigma_{e j}^{2}}$ & $\frac{\beta_{j}^{2}}{\sigma_{e j}^{2}}$ & $\sum_{j=1}^{i} \frac{\beta_{j}^{2}}{\sigma_{e j}^{2}}$ & $C_{i}$ \\
\hline 1 & 49 & 6.1833 & 0.0073 & 0.0073 & 0.0012 & 0.0012 & 0.00002 \\
\hline 2 & 134 & 4.2167 & 0.0039 & 0.0111 & 0.0009 & 0.0021 & 0.00003 \\
\hline 3 & 130 & 1.1259 & 0.0148 & 0.0260 & 0.0132 & 0.0153 & 0.00006 \\
\hline 4 & 107 & 1.0012 & 0.0135 & 0.0395 & 0.0135 & 0.0288 & 0.00010 \\
\hline 5 & 109 & 0.8374 & 0.0276 & 0.0671 & 0.0329 & 0.0617 & 0.00017 \\
\hline 6 & 135 & 0.6287 & 0.0516 & 0.1187 & 0.0821 & 0.1438 & 0.00029 \\
\hline 7 & 82 & 0.5761 & 0.0203 & 0.1390 & 0.0353 & 0.1791 & 0.00035 \\
\hline 8 & 106 & 0.4258 & 0.1135 & 0.2525 & 0.2666 & 0.4457 & 0.00063 \\
\hline 9 & 44 & 0.3861 & 0.1156 & 0.3682 & 0.2995 & 0.7452 & 0.00091 \\
\hline 10 & 61 & 0.3066 & 0.2533 & 0.6214 & 0.8262 & 1.5713 & 0.00154 \\
\hline 11 & 100 & 0.2588 & 0.0416 & 0.6631 & 0.1609 & 1.7322 & 0.00164 \\
\hline 12 & 114 & 0.2069 & 0.1415 & 0.8046 & 0.6838 & 2.4161 & 0.00199 \\
\hline 13 & 50 & 0.2031 & 0.1291 & 0.9337 & 0.6356 & 3.0517 & 0.00230 \\
\hline 14 & 84 & 0.1954 & 0.0619 & 0.9956 & 0.3169 & 3.3686 & 0.00245 \\
\hline 15 & 108 & 0.1947 & 0.1225 & 1.1181 & 0.6291 & 3.9976 & 0.00275 \\
\hline 16 & 81 & 0.1537 & 0.0786 & 1.1967 & 0.5114 & 4.5090 & 0.00294 \\
\hline
\end{tabular}


JEMA: Jurnal Ilmiah Bidang Akuntansi dan Manajemen, Vol. 16 No. 1 (2019) http://riset.unisma.ac.id/index.php/jema (e-ISSN : 2597-4071)

\begin{tabular}{|c|c|c|c|c|c|c|c|}
\hline Rank & Stock No. & $\frac{\bar{R}_{j}-R_{f}}{\beta_{j}}$ & $\frac{\left(\bar{R}_{j}-R_{f}\right) \beta_{j}}{\sigma_{e j}^{2}}$ & $\sum_{j=1}^{i} \frac{\left(\bar{R}_{j}-R_{f}\right) \beta_{j}}{\sigma_{e j}^{2}}$ & $\frac{\beta_{j}^{2}}{\sigma_{e j}^{2}}$ & $\sum_{j=1}^{i} \frac{\beta_{j}^{2}}{\sigma_{e j}^{2}}$ & $C_{i}$ \\
\hline 17 & 60 & 0.1528 & 0.1357 & 1.3324 & 0.8883 & 5.3973 & 0.00327 \\
\hline 18 & 128 & 0.1359 & 0.0945 & 1.4269 & 0.6959 & 6.0933 & 0.00349 \\
\hline 19 & 59 & 0.1270 & 0.2025 & 1.6295 & 1.5950 & 7.6883 & 0.00397 \\
\hline 20 & 102 & 0.1211 & 0.2675 & 1.8970 & 2.2082 & 9.8965 & 0.00460 \\
\hline 21 & 125 & 0.1186 & 0.0325 & 1.9295 & 0.2738 & 10.1703 & 0.00468 \\
\hline 22 & 103 & 0.1176 & 0.2264 & 2.1559 & 1.9256 & 12.0959 & 0.00520 \\
\hline 23 & 90 & 0.1047 & 0.0410 & 2.1969 & 0.3919 & 12.4878 & 0.00529 \\
\hline 24 & 113 & 0.1010 & 0.1387 & 2.3356 & 1.3734 & 13.8611 & 0.00561 \\
\hline 25 & 104 & 0.0992 & 0.0801 & 2.4158 & 0.8079 & 14.6690 & 0.00579 \\
\hline 26 & 105 & 0.0936 & 0.1938 & 2.6096 & 2.0704 & 16.7394 & 0.00622 \\
\hline 27 & 64 & 0.0896 & 0.0943 & 2.7038 & 1.0528 & 17.7922 & 0.00643 \\
\hline 28 & 48 & 0.0868 & 0.1199 & 2.8237 & 1.3806 & 19.1728 & 0.00670 \\
\hline 29 & 87 & 0.0819 & 0.1334 & 2.9571 & 1.6285 & 20.8013 & 0.00699 \\
\hline 30 & 25 & 0.0722 & 0.3478 & 3.3050 & 4.8185 & 25.6198 & 0.00772 \\
\hline 31 & 123 & 0.0647 & 0.1242 & 3.4291 & 1.9183 & 27.5381 & 0.00797 \\
\hline 32 & 36 & 0.0631 & 0.2517 & 3.6809 & 3.9896 & 31.5277 & 0.00848 \\
\hline 33 & 67 & 0.0618 & 0.3244 & 4.0052 & 5.2473 & 36.7750 & 0.00912 \\
\hline 34 & 54 & 0.0613 & 0.2144 & 4.2197 & 3.4989 & 40.2739 & 0.00953 \\
\hline 35 & 52 & 0.0565 & 0.3183 & 4.5379 & 5.6297 & 45.9035 & 0.01012 \\
\hline 36 & 43 & 0.0513 & 0.1049 & 4.6428 & 2.0452 & 47.9487 & 0.01031 \\
\hline 37 & 131 & 0.0511 & 0.1841 & 4.8269 & 3.6000 & 51.5487 & 0.01063 \\
\hline 38 & 118 & 0.0508 & 0.0415 & 4.8684 & 0.8164 & 52.3652 & 0.01070 \\
\hline 39 & 132 & 0.0496 & 0.4443 & 5.3127 & 8.9565 & 61.3217 & 0.01145 \\
\hline 40 & 28 & 0.0426 & 0.1613 & 5.4740 & 3.7847 & 65.1064 & 0.01171 \\
\hline 41 & 133 & 0.0290 & 0.1108 & 5.5848 & 3.8159 & 68.9222 & 0.01185 \\
\hline 42 & 116 & 0.0285 & 0.0541 & 5.6388 & 1.8946 & 70.8169 & 0.01191 \\
\hline 43 & 101 & 0.0280 & 0.3158 & 5.9546 & 11.2757 & 82.0925 & 0.01229 \\
\hline 44 & 68 & 0.0267 & 0.0759 & 6.0305 & 2.8452 & 84.9377 & 0.01237 \\
\hline 45 & 120 & 0.0254 & 0.1475 & 6.1780 & 5.8076 & 90.7453 & 0.01253 \\
\hline 46 & 18 & 0.0240 & 0.2192 & 6.3972 & 9.1414 & 99.8867 & 0.01273 \\
\hline 47 & 2 & 0.0223 & 0.1510 & 6.5481 & 6.7828 & 106.6695 & 0.01286 \\
\hline 48 & 110 & 0.0222 & 0.0598 & 6.6079 & 2.6927 & 109.3622 & 0.01291 \\
\hline 49 & 111 & 0.0219 & 0.5929 & 7.2008 & 27.0920 & 136.4542 & 0.01336 \\
\hline 50 & 121 & 0.0195 & 0.1831 & 7.3839 & 9.4061 & 145.8602 & 0.01347 \\
\hline 51 & 119 & 0.0193 & 0.0034 & 7.3873 & 0.1762 & 146.0365 & 0.01347 \\
\hline 52 & 46 & 0.0172 & 0.0635 & 7.4508 & 3.6943 & 149.7308 & 0.01349 \\
\hline 53 & 91 & 0.0162 & 0.0283 & 7.4791 & 1.7408 & 151.4716 & 0.01350 \\
\hline
\end{tabular}




\begin{tabular}{|c|c|c|c|c|c|c|c|}
\hline Rank & Stock No. & $\frac{\bar{R}_{j}-R_{f}}{\beta_{j}}$ & $\frac{\left(\bar{R}_{j}-R_{f}\right) \beta_{j}}{\sigma_{e j}^{2}}$ & $\sum_{j=1}^{i} \frac{\left(\bar{R}_{j}-R_{f}\right) \beta_{j}}{\sigma_{e j}^{2}}$ & $\frac{\beta_{j}^{2}}{\sigma_{e j}^{2}}$ & $\sum_{j=1}^{i} \frac{\beta_{j}^{2}}{\sigma_{e j}^{2}}$ & $C_{i}$ \\
\hline 54 & 78 & 0.0145 & 0.0944 & 7.5735 & 6.5132 & 157.9849 & $\mathbf{0 . 0 1 3 5 1}$ \\
\hline 55 & 74 & 0.0108 & 0.0431 & 7.6166 & 3.9735 & 161.9583 & 0.01349 \\
\hline 56 & 22 & 0.0087 & 0.0587 & 7.6753 & 6.7159 & 168.6742 & 0.01344 \\
\hline 57 & 39 & 0.0083 & 0.0254 & 7.7008 & 3.0653 & 171.7395 & 0.01341 \\
\hline 58 & 55 & 0.0080 & 0.0509 & 7.7516 & 6.3729 & 178.1124 & 0.01335 \\
\hline 59 & 76 & 0.0056 & 0.0483 & 7.8000 & 8.7019 & 186.8143 & 0.01324 \\
\hline 60 & 16 & 0.0050 & 0.0542 & 7.8542 & 10.9465 & 197.7608 & 0.01308 \\
\hline 61 & 10 & 0.0048 & 0.1366 & 7.9908 & 28.5501 & 226.3108 & 0.01271 \\
\hline 62 & 164 & 0.0044 & 0.0032 & 7.9940 & 0.7142 & 227.0250 & 0.01270 \\
\hline 63 & 122 & 0.0041 & 0.0094 & 8.0034 & 2.3078 & 229.3328 & 0.01267 \\
\hline 64 & 26 & 0.0034 & 0.0181 & 8.0215 & 5.3407 & 234.6735 & 0.01259 \\
\hline 65 & 129 & 0.0032 & 0.0142 & 8.0358 & 4.3931 & 239.0666 & 0.01253 \\
\hline 66 & 117 & 0.0029 & 0.0288 & 8.0646 & 9.9684 & 249.0350 & 0.01238 \\
\hline 67 & 77 & 0.0020 & 0.0144 & 8.0790 & 7.0901 & 256.1252 & 0.01227 \\
\hline 68 & 73 & 0.0019 & 0.0140 & 8.0930 & 7.2801 & 263.4053 & 0.01215 \\
\hline 69 & 89 & 0.0007 & 0.0043 & 8.0973 & 6.4328 & 269.8381 & 0.01204 \\
\hline 70 & 11 & 0.0002 & 0.0012 & 8.0985 & 6.3358 & 276.1739 & 0.01193 \\
\hline
\end{tabular}

Source: Secondary Data Processed, 2018

From Table 2, it is apparent that the highest $C_{i}$ value is 0.01351 for stock number 78 , i.e. MJL Bangladesh Limited; hence, the cutoff rate $\left(C^{*}\right)$ is 0.01351 . Sixteen stocks have an excess return-tobeta ratio below the $C^{*}$, therefore are excluded from the optimal portfolio. So according to Sharpe's single-index model, the remaining fifty-four stocks, having an excess return-to-beta ratio above the $C^{*}$, qualify to be a part of the optimal portfolio.

\subsection{Research Discussion}

\subsubsection{Constructing the Optimal Portfolio}

Sharpe's single-index model not only identifies the stocks to be included in the optimal portfolio but also recommends the proportion of fund to be invested in each of them. Thus, the investors can reduce the unsystematic risk and construct a highly diversified portfolio. The following chart (Table 3) depicts the proportion of investment to be made on the fifty-four stocks qualified for the optimal portfolio.

Table 3 Weight of Stocks in the Optimal Portfolio

\begin{tabular}{|c|c|l|c|c|}
\hline Rank & Stock No. & \multicolumn{1}{|c|}{ Name } & $Z_{i}$ & Weight $\left(X_{i}\right)$ \\
\hline 1 & 49 & Renwick Jajneswar \& Co (Bd) Ltd. & 1.01938 & $2.3242 \%$ \\
\hline 2 & 134 & Legacy Footwear Ltd. & 0.42581 & $0.9709 \%$ \\
\hline 3 & 130 & Grameenphone Ltd. & 0.46446 & $1.0590 \%$ \\
\hline 4 & 107 & Kohinoor Chemicals Company (Bangladesh) Ltd. & 1.04414 & $2.3806 \%$ \\
\hline 5 & 109 & Libra Infusions Limited & 1.03220 & $2.3534 \%$ \\
\hline 6 & 135 & Monno Ceramic Industries Ltd. & 1.03242 & $2.3539 \%$ \\
\hline
\end{tabular}


JEMA: Jurnal Ilmiah Bidang Akuntansi dan Manajemen, Vol. 16 No. 1 (2019)

http://riset.unisma.ac.id/index.php/jema (e-ISSN : 2597-4071)

\begin{tabular}{|c|c|c|c|c|}
\hline Rank & Stock No. & Name & $Z_{i}$ & Weight $\left(X_{i}\right)$ \\
\hline 7 & 82 & Al-Haj Textile Mills Limited & 0.62054 & $1.4148 \%$ \\
\hline 8 & 106 & Pharma Aids Ltd. & 2.19126 & $4.9961 \%$ \\
\hline 9 & 44 & Eastern Cables Ltd. & 1.60392 & $3.6570 \%$ \\
\hline 10 & 61 & British American Tobacco Bangladesh Company Ltd. & 3.57568 & $8.1526 \%$ \\
\hline 11 & 100 & Ambee Pharma Ltd. & 0.92550 & $2.1102 \%$ \\
\hline 12 & 114 & Marico Bangladesh Ltd. & 1.64882 & $3.7593 \%$ \\
\hline 13 & 50 & National tubes Ltd. & 0.94147 & $2.1466 \%$ \\
\hline 14 & 84 & Rahim Textile Mills Ltd. & 0.59819 & $1.3639 \%$ \\
\hline 15 & 108 & The IBN SINA Pharmaceutical Industry Ltd. & 1.21949 & $2.7805 \%$ \\
\hline 16 & 81 & Sonali Aansh Industries Limited & 0.88817 & $2.0250 \%$ \\
\hline 17 & 60 & Apex Foods Limited & 1.03144 & $2.3517 \%$ \\
\hline 18 & 128 & Daffodil Computers Ltd. & 0.86783 & $1.9787 \%$ \\
\hline 19 & 59 & Olympic Industries Limited & 1.33037 & $3.0332 \%$ \\
\hline 20 & 102 & GlaxoSmithKline(GSK) Bangladesh Limited & 1.74671 & $3.9825 \%$ \\
\hline 21 & 125 & BDCOM Online Ltd. & 0.35259 & $0.8039 \%$ \\
\hline 22 & 103 & ACI Limited. & 1.30947 & $2.9856 \%$ \\
\hline 23 & 90 & Anlima Yarn Dyeing Ltd. & 0.45627 & $1.0403 \%$ \\
\hline 24 & 113 & ACI Formulations Ltd. & 0.70168 & $1.5998 \%$ \\
\hline 25 & 104 & Renata Ltd. & 0.82110 & $1.8721 \%$ \\
\hline 26 & 105 & Reckitt Benckiser (Bd.)Ltd. & 1.18977 & $2.7127 \%$ \\
\hline 27 & 64 & Agricultural Marketing Company Ltd. (Pran) & 0.76257 & $1.7387 \%$ \\
\hline 28 & 48 & Quasem Drycells Ltd. & 0.61289 & $1.3974 \%$ \\
\hline 29 & 87 & Apex Spinning \& Knitting Mills Limited & 0.79501 & $1.8126 \%$ \\
\hline 30 & 25 & BRAC Bank Ltd. & 1.31509 & $2.9984 \%$ \\
\hline 31 & 123 & Lafarge Surma Cement Ltd. & 0.55550 & $1.2665 \%$ \\
\hline 32 & 36 & IPDC Finance Limited & 0.87316 & $1.9908 \%$ \\
\hline 33 & 67 & Linde Bangladesh Limited & 1.23684 & $2.8200 \%$ \\
\hline 34 & 54 & National Polymer Industries Ltd & 0.90478 & $2.0629 \%$ \\
\hline 35 & 52 & Rangpur Foundry Ltd. & 1.30733 & $2.9807 \%$ \\
\hline 36 & 43 & Bangladesh Lamps Limited & 0.47902 & $1.0922 \%$ \\
\hline 37 & 131 & Apex Tannery Limited & 0.59892 & $1.3655 \%$ \\
\hline 38 & 118 & Summit Alliance Port Limited & 0.19958 & $0.4550 \%$ \\
\hline 39 & 132 & Bata Shoe Company (Bangladesh) Limited & 1.46201 & $3.3334 \%$ \\
\hline 40 & 28 & Trust Bank Ltd. & 0.47989 & $1.0942 \%$ \\
\hline 41 & 133 & Apex Footwear Limited & 0.28786 & $0.6563 \%$ \\
\hline 42 & 116 & Samorita Hospital Ltd. & 0.21311 & $0.4859 \%$ \\
\hline 43 & 101 & Beximco Pharmaceuticals Ltd. & 0.53449 & $1.2187 \%$ \\
\hline 44 & 68 & Padma Oil Co.Ltd. & 0.18160 & $0.4141 \%$ \\
\hline 45 & 120 & Heidelberg Cement Bangladesh Ltd. & 0.30133 & $0.6870 \%$ \\
\hline 46 & 18 & Mutual Trust Bank Ltd. & 0.35594 & $0.8116 \%$ \\
\hline 47 & 2 & The City Bank Ltd. & 0.20815 & $0.4746 \%$ \\
\hline 48 & 110 & Orion Infusion Ltd. & 0.13563 & $0.3092 \%$ \\
\hline 49 & 111 & Square Pharmaceuticals Ltd. & 0.72062 & $1.6430 \%$ \\
\hline 50 & 121 & Confidence Cement Ltd. & 0.17536 & $0.3998 \%$ \\
\hline
\end{tabular}


JEMA: Jurnal Ilmiah Bidang Akuntansi dan Manajemen, Vol. 16 No. 1 (2019)

http://riset.unisma.ac.id/index.php/jema (e-ISSN : 2597-4071)

\begin{tabular}{|c|c|l|c|c|}
\hline Rank & Stock No. & \multicolumn{1}{|c|}{ Name } & $Z_{i}$ & Weight $\left(X_{i}\right)$ \\
\hline 51 & 119 & Unique Hotel \& Resorts Limited & 0.01107 & $0.0252 \%$ \\
\hline 52 & 46 & Singer Bangladesh Ltd. & 0.05939 & $0.1354 \%$ \\
\hline 53 & 91 & H.R. Textile Ltd. & 0.02716 & $0.0619 \%$ \\
\hline 54 & 78 & MJL Bangladesh Limited & 0.02648 & $0.0604 \%$ \\
\hline \multicolumn{4}{|r|}{$\sum Z_{i}=43.85946$} & $100.00 \%$ \\
\hline
\end{tabular}

Source: Secondary Data Processed, 2018

As shown in Table 3, the largest chunk of investment $(8.1526 \%)$ should be made in British American Tobacco Bangladesh Company Ltd., followed by Pharma Aids Ltd. and GlaxoSmithKline (GSK) Bangladesh Limited with an investment proportion of $4.9961 \%$ and $3.9825 \%$, respectively. A sector-wise study on the fifty-four stocks in our optimal portfolio, shown in Picture 2, reveals that most of them belong to three industries: Pharmaceuticals \& Chemicals, Engineering, and Food \& Allied. These three industrial sectors account for 65.78 percent of the total investment to be made in the optimal portfolio, while the rest of the twelve sectors represent only 34.22 percent of the total investment.

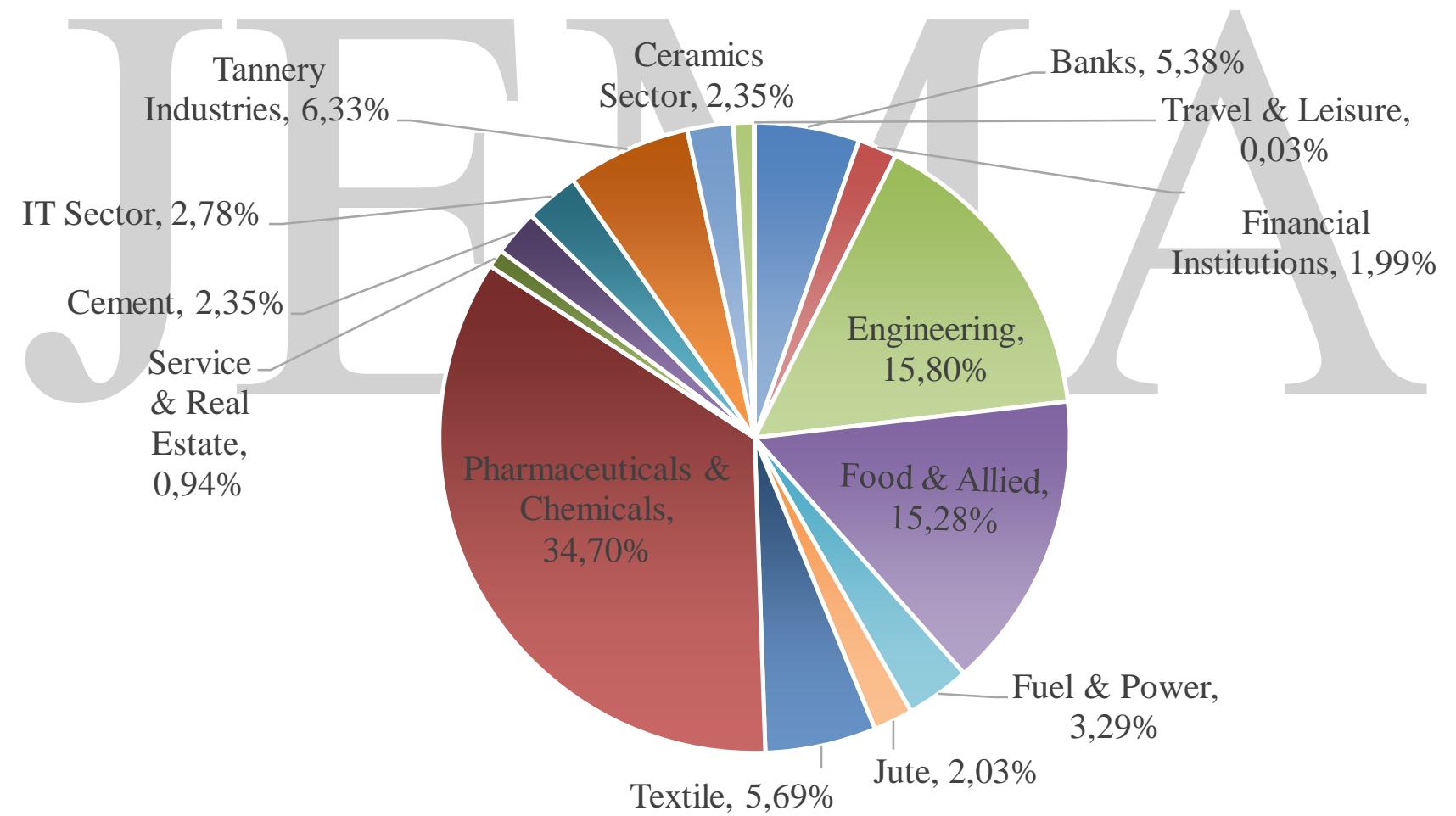

Picture 3 Sector-Wise Proportion of Investment (Secondary Data Processed, 2018)

From the above pie chart (Picture 2), it is evident that Pharmaceuticals \& Chemicals sector occupies the highest proportion of fund to be invested in the optimal portfolio, followed by Engineering and Food \& Allied industry. Among the sixteen industrial sectors selected for this study, all but Insurance sector have at least one representative stock in the final portfolio. Hence, the final portfolio has stocks from fifteen industrial sectors that react differently to the changes in economic forces. 


\subsubsection{Performance of Optimal Portfolio}

Once we have decided about the stocks along with their respective weights in the optimal portfolio, the final task is to evaluate its overall performance. Therefore, the performance of the constructed portfolio in terms of risk and return is calculated, and the key results are summarized in Table 4. For detailed calculations, refer to Appendix-D.

Table 4 Evaluation of Portfolio Performance

\begin{tabular}{|c|c|c|c|}
\hline \multicolumn{2}{|c|}{ Portfolio Return Calculation } & \multicolumn{2}{|l|}{ Portfolio Risk Calculation } \\
\hline Alpha on Portfolio $\left(\alpha_{p}\right)=$ & 0.020644 & $\sum_{i=1}^{N} X_{i}^{2} \sigma_{e i}^{2}=$ & 0.0003427 \\
\hline Beta on Portfolio $\left(\beta_{p}\right)=$ & 0.124003 & $\beta_{p}^{2} \sigma_{m}^{2}=$ & 0.0000382 \\
\hline Return on Market Index $\left(\bar{R}_{m}\right)=$ & $0.6812 \%$ & Portfolio Standard Deviation $\left(\sigma_{p}\right)=$ & $1.9516 \%$ \\
\hline Portfolio Return $\left.\overline{(R}_{p}\right)=$ & $2.1489 \%$ & Portfolio Coefficient of Variation $(\mathrm{CV})=$ & $90.8184 \%$ \\
\hline
\end{tabular}

Source: Secondary Data Processed, 2018

As apparent from the above table (Table 4), the constructed portfolio offers a generous monthly return of 2.1489 percent. However, the portfolio risk, measured by the standard deviation, is only 1.9516 percent. The portfolio has a CV of 90.8184 percent, a rate that is considerably lower than any individual stock in the optimal portfolio. The portfolio beta, expressing the systematic risk, also leads us to the identical conclusion. A comparison of the portfolio beta with that of the market indicates a substantial absence of systematic risk in the constructed one. The results of this study conform to the earlier researches conducted on portfolio optimization. Since the portfolio formed using Sharpe's single-index model offers the best risk-return combinations possible in the given context, the portfolio can be termed as the optimal portfolio and the stocks consisting this portfolio as the efficient stocks.

\section{RESEARCH CONCLUSION AND LIMITATION}

\subsection{Conclusion}

In addition to simplifying the portfolio construction process, Sharpe's single-index model reduces the number of inputs required to form the optimal portfolio. If we were to form a portfolio using the same number of stocks, Markowitz's model would require 16,109 inputs. Whereas, Sharpe's model required only 536 inputs, which is about 2,905 percent less than that of its predecessor. The findings of the study reveal a huge possibility of risk reduction through diversification while achieving a substantial return for Bangladeshi investors. The constructed portfolio outperforms every individual stock as well as the market index in terms of offering the optimal risk-return combinations. Therefore, this five-and-a-half-decade-old model offers a great opportunity for Bangladeshi investors to optimize return and diversify risk in an efficient manner. Nevertheless, investors should not slack off at this point. They need to evaluate the performance of each stock and make necessary amendments in the optimal portfolio at regular intervals. Otherwise, the risk may go up and return may go down, evaporating the benefits of portfolio optimization. 


\subsection{Limitation}

This study certainly has some limitations. The stocks selected for this study belong to only "A" category companies traded on DSE. Future studies may consider the stocks from other categories and from Chittagong Stock Exchange (CSE), the second bourse of Bangladesh. In addition, the study has excluded fifty "A" category stocks for lack of data. Although the monthly closing price data of five years and two months was adequate to form an optimal portfolio, daily closing price data and longer time horizon may result in better optimization of risk \& return. As the study focused on simplifying the Markowitz's model of portfolio optimization using Sharpe's model, a side-by-side comparison of portfolios formed using both techniques can enhance or diminish the credibility of our hypothesis. Lastly, allowing short sales may change the nature of the optimal solution, as stocks having opposite characteristics will be a part of the optimal portfolio.

\section{REFERENCES}

Ahuja, R. (2017). Sharpe Single Index Model: Evidence From Bombay Stock Exchange (BSE) in India. Research Bulletin, 43(1).

Bodie, Z., Kane, A., \& Marcus, A. J. (2009). Investments, Eight Edition. International Edition. New York: McGraw-Hill/Irwin.

Briec, W., \& Kerstens, K. (2009). Multi-Horizon Markowitz Portfolio Performance Appraisals: A General Approach. Omega, 37(1): 50-62. https://hal.archives-ouvertes.fr/hal-00288174.

Dhaka Stock Exchange. (2017). Annual Report 2016-17. Dhaka: Dhaka Stock Exchange Ltd. Retrieved from http://www.dsebd.org/download/Annual_Report.zip

Dhaka Stock Exchange. (2018). DSE Clearing and Settlement System. Retrieved from www.dsebd.org/settle.php.

Elton, E. J., Gruber, M. J., \& Padberg, M. W. (1976). Simple Criteria For Optimal Portfolio Selection. The Journal of Finance, 31(5), 1341-1357. https://doi.org/10.1111/j.15406261.1976.tb03217.x.

Elton, E. J., Gruber, M. J., \& Padberg, M. W. (1977). Simple Rules For Optimal Portfolio Selection: The Multi Group Case. Journal of Financial and Quantitative Analysis, 12(3), 329-345. https://doi.org/10.2307/2330538.

Elton, E. J., Gruber, M. J., \& Padberg, M. W. (1978). Simple Criteria For Optimal Portfolio Selection: Tracing Out The Efficient Frontier. The Journal of Finance, 33(1), 296-302. https://doi.org/10.2307/2326368.

Elton, E. J., Gruber, M. J., Brown, S. J., \& Goetzmann, W. N. (2009). Modern Portfolio Theory And Investment Analysis. New York: Wiley.

Frankfurter, G. M., Phillips, H. E., \& Seagle, J. P. (1976). Performance Of The Sharpe Portfolio Selection Model: A Comparison. Journal of Financial and Quantitative Analysis, 11(2), 195204. https://doi.org/10.2307/2979049.

Haugen, R. (1993). Modern Investment Theory, Third Edition. New Jersey: Prentice-Hall.

Markowitz, H. (1952). Portfolio Selection. The journal of finance, 7(1), 77-91. https://doi.org/10.1111/j.1540-6261.1952.tb01525.x. 
Nanda, S. R., Mahanty, B., \& Tiwari, M. K. (2010). Clustering Indian Stock Market Data For Portfolio Management. Expert Systems with Applications, 37(12), 8793-8798. https://doi.org/10.1016/j.eswa.2010.06.026.

Omet, G. (1995). On The Performance Of Alternative Portfolio Selection Models. Dirasat (The Humanities), 22(3), 125-135.

Paudel, R. B., \& Koirala, S. (2007). Application of Markowitz and Sharpe Models in Nepalese Stock. Journal of Nepalese Business Studies, 3(1), 18-35.

Rahaman, M. A., Hasan, M. B., \& Ahsan, A. M. (2013). Stock Market Performance Under Different Government Periods: Evidence from Bangladesh. Universal Journal of Accounting and Finance, 1(2), 42-50. https://doi.org/10.13189/ujaf.2013.010202.

Rani, M., \& Bahl, S. (2012). Optimal Portfolio Selection With Or Without The Procedure Of Short Sales. Asian Journal of Research in Business Economics and Management, 2(7), 220-234.

Sen, K., \& Fattawat, C. D. (2014). Sharpe's Single Index Model and its Application Portfolio Construction: An Empirical Study. Global Journal of Finance and Management, 6(6), 511516.

Sharpe, W. F. (1963). A Simplified Model For Portfolio Analysis. Management Science, 9(2), $277-$ 293. https://dx.doi.org/10.1287/mnsc.9.2.277.

Singh, S., \& Gautam, J. (2014). The Single Index Model \& The Construction Of Optimal Portfolio: A Case Of Banks Listed On NSE India. Risk governance \& control: financial markets \& institutions, 4(2), 110-115. https://doi.org/10.22495/rgcv4i2c1art3.

Skarica, B., \& Zrinka, L. (2012). A Comparison of Basic and Extended Markowitz Model on Croatian Capital Market. Croatian Operational Research (CRORR), 3(1), 236-244. Retrieved from https://hrcak.srce.hr/96823.

*) Imroz Mahmud, Department of Business Administration, University of Asia Pacific, Dhaka, Bangladesh (Email: imroz@outlook.com) 
JEMA: Jurnal Ilmiah Bidang Akuntansi dan Manajemen, Vol. 16 No. 1 (2019)

http://riset.unisma.ac.id/index.php/jema (e-ISSN : 2597-4071)

\section{Appendix-A:}

Risk and return characteristics of 178 sample stocks and the benchmark market index (DSEX) with

Code A as Stock Number

Code E as Standard Deviation

Code B as Name

Code $\mathrm{F}$ as Covariance

Code $\mathrm{C}$ as Mean Return

Code $\mathrm{G}$ as Beta

Code D as Variance

\begin{tabular}{|c|c|c|c|c|c|c|}
\hline $\mathbf{A}$ & $\mathbf{B}$ & $\mathbf{C}$ & $\mathbf{D}$ & $\mathbf{E}$ & $\mathbf{F}$ & $\mathbf{G}$ \\
\hline 1 & AB Bank Limited & -0.00260 & 0.01528 & 0.12360 & 0.00339 & 0.22182 \\
\hline 2 & The City Bank Ltd. & 0.01113 & 0.01217 & 0.11032 & 0.00347 & 0.28493 \\
\hline 3 & IFIC Bank Ltd. & -0.00070 & 0.02645 & 0.16264 & 0.00326 & 0.12338 \\
\hline 4 & Islami Bank Bd Ltd & 0.00209 & 0.01626 & 0.12751 & 0.00250 & 0.15359 \\
\hline 5 & National Bank Ltd. & -0.00479 & 0.01138 & 0.10666 & 0.00262 & 0.23006 \\
\hline 6 & Pubali Bank Ltd. & -0.00084 & 0.00694 & 0.08332 & 0.00188 & 0.27022 \\
\hline 7 & Rupali Bank Ltd. & 0.00042 & 0.01736 & 0.13175 & 0.00322 & 0.18556 \\
\hline 8 & United Commercial Bank Ltd. & 0.00287 & 0.01029 & 0.10145 & 0.00288 & 0.28005 \\
\hline 9 & Uttara Bank Ltd. & 0.00001 & 0.00809 & 0.08996 & 0.00265 & 0.32736 \\
\hline 10 & Eastern Bank Ltd. & 0.00650 & 0.00485 & 0.06963 & 0.00174 & 0.35953 \\
\hline 11 & Al-Arafah Islami Bank Ltd. & 0.00484 & 0.01143 & 0.10692 & 0.00305 & 0.26704 \\
\hline 12 & Prime Bank Ltd. & -0.00472 & 0.00863 & 0.09288 & 0.00168 & 0.19448 \\
\hline 13 & Southeast Bank Ltd. & 0.00426 & 0.00812 & 0.09009 & 0.00259 & 0.31930 \\
\hline 14 & Dhaka Bank Ltd. & -0.00096 & 0.01042 & 0.10209 & 0.00341 & 0.32680 \\
\hline 15 & National Credit and Commerce Bank Ltd. & 0.00091 & 0.00520 & 0.07214 & 0.00208 & 0.39944 \\
\hline 16 & Social Islami Bank Ltd. & 0.00599 & 0.00553 & 0.07434 & 0.00134 & 0.24267 \\
\hline 17 & Dutch-Bangla Bank Ltd. & 0.00311 & 0.00657 & 0.08106 & 0.00215 & 0.32799 \\
\hline 18 & Mutual Trust Bank Ltd. & 0.01123 & 0.00808 & 0.08991 & 0.00217 & 0.26881 \\
\hline 19 & Standard Bank Ltd. & -0.00235 & 0.00887 & 0.09419 & 0.00288 & 0.32447 \\
\hline 20 & One Bank Limited & 0.00212 & 0.00805 & 0.08971 & 0.00296 & 0.36771 \\
\hline 21 & Bank Asia Ltd. & 0.00429 & 0.00826 & 0.09086 & 0.00196 & 0.23776 \\
\hline 22 & Mercantile Bank Ltd. & 0.00689 & 0.00882 & 0.09391 & 0.00213 & 0.24136 \\
\hline 23 & Export Import (Exim) Bank of Bangladesh Ltd. & -0.00260 & 0.00646 & 0.08035 & 0.00203 & 0.31399 \\
\hline 24 & Jamuna Bank Ltd. & 0.00131 & 0.00565 & 0.07516 & 0.00160 & 0.28406 \\
\hline 25 & BRAC Bank Ltd. & 0.02030 & 0.00971 & 0.09852 & 0.00209 & 0.21499 \\
\hline 26 & Shahjalal Islami Bank Ltd. & 0.00553 & 0.00910 & 0.09539 & 0.00199 & 0.21899 \\
\hline 27 & Premier Bank Ltd. & 0.00008 & 0.00854 & 0.09241 & 0.00235 & 0.27575 \\
\hline 28 & Trust Bank Ltd. & 0.01457 & 0.01406 & 0.11857 & 0.00323 & 0.22960 \\
\hline 29 & First Security Islami Bank Ltd. & -0.00085 & 0.00919 & 0.09588 & 0.00268 & 0.29198 \\
\hline 30 & IDLC Finance Limited & 0.00461 & 0.01739 & 0.13186 & 0.00480 & 0.27608 \\
\hline 31 & United Finance Limited & -0.00221 & 0.01157 & 0.10756 & 0.00361 & 0.31180 \\
\hline 32 & Uttara Finance and Investments Limited. & -0.00008 & 0.00815 & 0.09029 & 0.00328 & 0.40203 \\
\hline 33 & Premier Leasing \& Finance Limited. & 0.00417 & 0.01478 & 0.12157 & 0.00337 & 0.22791 \\
\hline 34 & Islamic Finance \& Investment Ltd. & 0.00183 & 0.01323 & 0.11500 & 0.00361 & 0.27282 \\
\hline 35 & LankaBangla Finance Ltd. & 0.00469 & 0.02970 & 0.17233 & 0.00560 & 0.18862 \\
\hline
\end{tabular}


JEMA: Jurnal Ilmiah Bidang Akuntansi dan Manajemen, Vol. 16 No. 1 (2019) http://riset.unisma.ac.id/index.php/jema (e-ISSN : 2597-4071)

\begin{tabular}{|c|c|c|c|c|c|c|}
\hline $\mathbf{A}$ & B & $\mathbf{C}$ & $\mathbf{D}$ & $\mathbf{E}$ & $\mathbf{F}$ & $\mathbf{G}$ \\
\hline 36 & IPDC Finance Limited & 0.01908 & 0.01299 & 0.11399 & 0.00294 & 0.22657 \\
\hline 37 & Union Capital Ltd. & 0.00067 & 0.02101 & 0.14493 & 0.00406 & 0.19313 \\
\hline 38 & Bangladesh Finance and Investment Co. Ltd. & 0.00371 & 0.02006 & 0.14165 & 0.00466 & 0.23210 \\
\hline 39 & Phoenix Finance and Investments Ltd. & 0.00683 & 0.02006 & 0.14162 & 0.00495 & 0.24701 \\
\hline 40 & Bay Leasing \& Investment Ltd. & 0.00281 & 0.01693 & 0.13011 & 0.00360 & 0.21247 \\
\hline 41 & GSP Finance Company (Bangladesh) Limited & 0.00478 & 0.02556 & 0.15987 & 0.00384 & 0.15041 \\
\hline 42 & Aftab Automobiles Limited & 0.00066 & 0.01322 & 0.11499 & 0.00374 & 0.28280 \\
\hline 43 & Bangladesh Lamps Limited & 0.01305 & 0.01277 & 0.11302 & 0.00206 & 0.16122 \\
\hline 44 & Eastern Cables Ltd. & 0.03165 & 0.01617 & 0.12718 & 0.00113 & 0.06957 \\
\hline 45 & Monno Jute Stafflers Ltd. & 0.03474 & 0.01998 & 0.14137 & -0.00091 & -0.04531 \\
\hline 46 & Singer Bangladesh Ltd. & 0.00873 & 0.01435 & 0.11977 & 0.00329 & 0.22916 \\
\hline 47 & Atlas Bangladesh Ltd. & 0.00279 & 0.01168 & 0.10808 & 0.00238 & 0.20380 \\
\hline 48 & Quasem Drycells Ltd. & 0.01912 & 0.01982 & 0.14077 & 0.00327 & 0.16512 \\
\hline 49 & Renwick Jajneswar \& Co (Bd) Ltd. & 0.04892 & 0.04320 & 0.20785 & 0.00031 & 0.00714 \\
\hline 50 & National tubes Ltd. & 0.03079 & 0.02582 & 0.16070 & 0.00331 & 0.12802 \\
\hline 51 & Anwar Galvanizing Ltd. & 0.03342 & 0.02169 & 0.14729 & -0.00049 & -0.02251 \\
\hline 52 & Rangpur Foundry Ltd. & 0.01526 & 0.00618 & 0.07862 & 0.00115 & 0.18526 \\
\hline 53 & S. Alam Cold Rolled Steels Ltd. & -0.00368 & 0.00830 & 0.09110 & 0.00276 & 0.33294 \\
\hline 54 & National Polymer Industries Ltd & 0.01611 & 0.00984 & 0.09920 & 0.00182 & 0.18475 \\
\hline 55 & BSRM Steels Limited & 0.00718 & 0.01438 & 0.11994 & 0.00432 & 0.30040 \\
\hline 56 & Navana CNG Limited & 0.00088 & 0.01116 & 0.10566 & 0.00378 & 0.33858 \\
\hline 57 & Deshbandhu Polymer Limited & 0.00194 & 0.01373 & 0.11719 & 0.00221 & 0.16092 \\
\hline 58 & GPH Ispat Ltd. & 0.00326 & 0.01568 & 0.12520 & 0.00425 & 0.27131 \\
\hline 59 & Olympic Industries Limited & 0.02206 & 0.01165 & 0.10793 & 0.00158 & 0.13604 \\
\hline 60 & Apex Foods Limited & & 0.01623 & 0.12740 & 0.00195 & .11994 \\
\hline 61 & British American Tobacco Bangladesh Company Ltd. & 0.02554 & 0.00556 & 0.07457 & 0.00038 & 0.06771 \\
\hline 62 & Gemini Sea Food Ltd. & 0.03379 & 0.04662 & 0.21592 & -0.00223 & -0.04778 \\
\hline 63 & National Tea Company Limited & -0.00264 & 0.00489 & 0.06994 & 0.00031 & 0.06378 \\
\hline 64 & Agricultural Marketing Company Ltd. (Pran) & 0.01419 & 0.01050 & 0.10245 & 0.00110 & 0.10499 \\
\hline 65 & Fu Wang Food Ltd. & 0.00218 & 0.01547 & 0.12438 & 0.00316 & 0.20425 \\
\hline 66 & Rangpur Dairy \& Food Products Limited & -0.00021 & 0.01674 & 0.12937 & 0.00325 & 0.19446 \\
\hline 67 & Linde Bangladesh Limited & 0.01745 & 0.00811 & 0.09004 & 0.00166 & 0.20492 \\
\hline 68 & Padma Oil Co.Ltd. & 0.01029 & 0.01505 & 0.12269 & 0.00310 & 0.20622 \\
\hline 69 & Eastern Lubricants Ltd. & 0.04159 & 0.05485 & 0.23421 & -0.00094 & -0.01710 \\
\hline 70 & Summit Power Ltd. & -0.00089 & 0.01099 & 0.10482 & 0.00401 & 0.36483 \\
\hline 71 & Dhaka Electric Supply Company Ltd. & -0.00548 & 0.00734 & 0.08568 & 0.00206 & 0.28067 \\
\hline 72 & Power Grid Company of Bangladesh Ltd. & 0.00283 & 0.00827 & 0.09094 & 0.00220 & 0.26586 \\
\hline 73 & Jamuna Oil Com. Ltd. & 0.00520 & 0.00647 & 0.08042 & 0.00139 & 0.21505 \\
\hline 74 & Meghna Petroleum Ltd. & 0.00688 & 0.00945 & 0.09721 & 0.00182 & 0.19282 \\
\hline 75 & Titas Gas Trans. \& Dist. Co. Ltd. & -0.00547 & 0.00374 & 0.06117 & 0.00154 & 0.41024 \\
\hline 76 & Khulna Power Company Ltd. & 0.00630 & 0.00871 & 0.09334 & 0.00237 & 0.27241 \\
\hline 77 & Baraka Power Limited & 0.00537 & 0.01206 & 0.10981 & 0.00349 & 0.28984 \\
\hline 78 & MJL Bangladesh Limited & 0.00831 & 0.00921 & 0.09598 & 0.00224 & 0.24299 \\
\hline 79 & GBB Power Limited & -0.00711 & 0.00969 & 0.09845 & 0.00354 & 0.36546 \\
\hline
\end{tabular}


JEMA: Jurnal Ilmiah Bidang Akuntansi dan Manajemen, Vol. 16 No. 1 (2019)

http://riset.unisma.ac.id/index.php/jema (e-ISSN : 2597-4071)

\begin{tabular}{|c|c|c|c|c|c|c|}
\hline $\mathbf{A}$ & B & $\mathbf{C}$ & D & $\mathbf{E}$ & $\mathbf{F}$ & $\mathbf{G}$ \\
\hline 80 & Northern Jute Manufacturing Co. Ltd. & 0.08227 & 0.07274 & 0.26969 & -0.00044 & -0.00611 \\
\hline 81 & Sonali Aansh Industries Limited & 0.01719 & 0.01276 & 0.11296 & 0.00103 & 0.08073 \\
\hline 82 & Al-Haj Textile Mills Limited & 0.02320 & 0.02898 & 0.17023 & 0.00093 & 0.03196 \\
\hline 83 & Stylecraft Limited & 0.02568 & 0.03174 & 0.17815 & -0.00033 & -0.01040 \\
\hline 84 & Rahim Textile Mills Ltd. & 0.02361 & 0.02932 & 0.17122 & 0.00282 & 0.09635 \\
\hline 85 & Saiham Textile Mills Ltd. & -0.00421 & 0.00634 & 0.07964 & 0.00218 & 0.34376 \\
\hline 86 & Desh Garments Ltd. & 0.05439 & 0.05976 & 0.24447 & -0.00093 & -0.01552 \\
\hline 87 & Apex Spinning \& Knitting Mills Limited & 0.01626 & 0.01211 & 0.11003 & 0.00170 & 0.14013 \\
\hline 88 & Delta Spinners Ltd. & -0.01595 & 0.01623 & 0.12739 & 0.00230 & 0.14202 \\
\hline 89 & Prime Textile Spinning Mills Ltd. & 0.00495 & 0.00908 & 0.09530 & 0.00218 & 0.23979 \\
\hline 90 & Anlima Yarn Dyeing Ltd. & 0.01299 & 0.01568 & 0.12523 & 0.00123 & 0.07836 \\
\hline 91 & H.R. Textile Ltd. & 0.00762 & 0.01759 & 0.13263 & 0.00307 & 0.17462 \\
\hline 92 & Alif Manufacturing Company Ltd. & -0.00579 & 0.02221 & 0.14902 & 0.00299 & 0.13463 \\
\hline 93 & Square Textiles Limited & -0.00935 & 0.00297 & 0.05449 & 0.00106 & 0.35771 \\
\hline 94 & R.N. Spinning Mills Ltd. & -0.00971 & 0.01274 & 0.11287 & 0.00128 & 0.10019 \\
\hline 95 & Malek Spinning Mills Ltd. & 0.00250 & 0.00885 & 0.09409 & 0.00184 & 0.20731 \\
\hline 96 & Zahintex Industries Limited & -0.00638 & 0.01283 & 0.11327 & 0.00170 & 0.13270 \\
\hline 97 & Saiham Cotton Mills Limited & -0.00905 & 0.00538 & 0.07334 & 0.00163 & 0.30217 \\
\hline 98 & Generation Next Fashions Limited & -0.01481 & 0.01303 & 0.11415 & 0.00250 & 0.19177 \\
\hline 99 & Envoy Textiles Limited & -0.00498 & 0.00458 & 0.06767 & 0.00098 & 0.21435 \\
\hline 100 & Ambee Pharma Ltd. & 0.01582 & 0.01131 & 0.10635 & 0.00048 & 0.04265 \\
\hline 101 & Beximco Pharmaceuticals Ltd. & 0.01334 & 0.00852 & 0.09230 & 0.00260 & 0.30569 \\
\hline 102 & GlaxoSmithKline(GSK) Bangladesh Limited & 0.02127 & 0.00843 & 0.09181 & 0.00115 & 0.13605 \\
\hline 103 & ACI Limited. & 0.02278 & 0.01222 & 0.11054 & 0.00187 & 0.15302 \\
\hline 104 & Renata Ltd. & 0.01314 & 0.00881 & 0.09385 & 0.00074 & 0.08427 \\
\hline 105 & Reckitt Benckiser (Bd.)Ltd. & 0.01783 & 0.00943 & 0.09711 & 0.00131 & 0.13937 \\
\hline 106 & Pharma Aids Ltd. & 0.02614 & 0.00944 & 0.09717 & 0.00047 & 0.05015 \\
\hline 107 & Kohinoor Chemicals Company (Bangladesh) Ltd. & 0.01758 & 0.01209 & 0.10994 & 0.00015 & 0.01278 \\
\hline 108 & The IBN SINA Pharmaceutical Industry Ltd. & 0.02298 & 0.01390 & 0.11791 & 0.00130 & 0.09345 \\
\hline 109 & Libra Infusions Limited & 0.02678 & 0.02097 & 0.14481 & 0.00055 & 0.02627 \\
\hline 110 & Orion Infusion Ltd. & 0.00861 & 0.01110 & 0.10535 & 0.00191 & 0.17229 \\
\hline 111 & Square Pharmaceuticals Ltd. & 0.01167 & 0.00390 & 0.06247 & 0.00123 & 0.31474 \\
\hline 112 & Keya Cosmetics Ltd. & -0.01192 & 0.01373 & 0.11718 & 0.00288 & 0.20939 \\
\hline 113 & ACI Formulations Ltd. & 0.02209 & 0.02144 & 0.14641 & 0.00367 & 0.17129 \\
\hline 114 & Marico Bangladesh Ltd. & 0.02138 & 0.00943 & 0.09709 & 0.00076 & 0.08022 \\
\hline 115 & Active Fine Chemicals Ltd. & -0.00861 & 0.00926 & 0.09624 & 0.00240 & 0.25872 \\
\hline 116 & Samorita Hospital Ltd. & 0.00859 & 0.00945 & 0.09722 & 0.00126 & 0.13350 \\
\hline 117 & Eastern Housing Limited & 0.00561 & 0.00847 & 0.09202 & 0.00243 & 0.28701 \\
\hline 118 & Summit Alliance Port Limited & 0.01253 & 0.02854 & 0.16893 & 0.00435 & 0.15249 \\
\hline 119 & Unique Hotel \& Resorts Limited & 0.00657 & 0.04854 & 0.22033 & 0.00449 & 0.09248 \\
\hline 120 & Heidelberg Cement Bangladesh Ltd. & 0.01060 & 0.00916 & 0.09571 & 0.00210 & 0.22901 \\
\hline 121 & Confidence Cement Ltd. & 0.01100 & 0.01109 & 0.10533 & 0.00354 & 0.31933 \\
\hline 122 & Meghna Cement Mills Ltd & 0.00562 & 0.01827 & 0.13515 & 0.00374 & 0.20473 \\
\hline 123 & Lafarge Surma Cement Ltd. & 0.01623 & 0.01639 & 0.12801 & 0.00290 & 0.17688 \\
\hline
\end{tabular}


JEMA: Jurnal Ilmiah Bidang Akuntansi dan Manajemen, Vol. 16 No. 1 (2019) http://riset.unisma.ac.id/index.php/jema (e-ISSN : 2597-4071)

\begin{tabular}{|c|c|c|c|c|c|c|}
\hline $\mathbf{A}$ & B & $\mathbf{C}$ & $\mathbf{D}$ & $\mathbf{E}$ & $\mathbf{F}$ & $\mathbf{G}$ \\
\hline 124 & M.I. Cement Factory Limited & 0.00162 & 0.00526 & 0.07252 & 0.00198 & 0.37557 \\
\hline 125 & BDCOM Online Ltd. & 0.01447 & 0.02435 & 0.15606 & 0.00199 & 0.08163 \\
\hline 126 & Intech Limited & 0.00470 & 0.01326 & 0.11514 & 0.00288 & 0.21731 \\
\hline 127 & Agni Systems Ltd. & 0.00136 & 0.00948 & 0.09736 & 0.00324 & 0.34223 \\
\hline 128 & Daffodil Computers Ltd. & 0.01811 & 0.01386 & 0.11771 & 0.00136 & 0.09811 \\
\hline 129 & aamra technologies limited & 0.00559 & 0.01429 & 0.11955 & 0.00356 & 0.24921 \\
\hline 130 & Grameenphone Ltd. & 0.04033 & 0.07562 & 0.27499 & 0.00239 & 0.03157 \\
\hline 131 & Apex Tannery Limited & 0.01635 & 0.01434 & 0.11976 & 0.00324 & 0.22622 \\
\hline 132 & Bata Shoe Company (Bangladesh) Limited & 0.01575 & 0.00558 & 0.07470 & 0.00123 & 0.22110 \\
\hline 133 & Apex Footwear Limited & 0.01076 & 0.01119 & 0.10579 & 0.00230 & 0.20568 \\
\hline 134 & Legacy Footwear Ltd. & 0.04283 & 0.08907 & 0.29845 & 0.00080 & 0.00902 \\
\hline 135 & Monno Ceramic Industries Ltd. & 0.03555 & 0.02916 & 0.17078 & 0.00143 & 0.04893 \\
\hline 136 & Fu-Wang Ceramic Industries Ltd. & 0.00094 & 0.01036 & 0.10179 & 0.00260 & 0.25127 \\
\hline 137 & RAK Ceramics (BD) Ltd. & 0.00204 & 0.01278 & 0.11303 & 0.00364 & 0.28468 \\
\hline 138 & Bangladesh General Insurance Company Ltd. & -0.00183 & 0.01372 & 0.11712 & 0.00375 & 0.27374 \\
\hline 139 & Green Delta Insurance Company Ltd. & 0.00062 & 0.00888 & 0.09422 & 0.00200 & 0.22480 \\
\hline 140 & United Insurance Company Ltd. & -0.00136 & 0.01537 & 0.12399 & 0.00408 & 0.26563 \\
\hline 141 & Peoples Insurance Company Ltd. & -0.00215 & 0.00622 & 0.07889 & 0.00222 & 0.35636 \\
\hline 142 & Eastern Insurance Co. Ltd. & -0.00274 & 0.00632 & 0.07948 & 0.00251 & 0.39755 \\
\hline 143 & Phoenix Insurance Company Ltd. & -0.00962 & 0.01097 & 0.10474 & 0.00263 & 0.23969 \\
\hline 144 & Eastland Insurance Company Limited & -0.01261 & 0.00995 & 0.09975 & 0.00310 & 0.31146 \\
\hline 145 & Central Insurance Company Limited & -0.00573 & 0.00663 & 0.08143 & 0.00139 & 0.20969 \\
\hline 146 & Karnaphuli Insurance Co. Ltd. & -0.00853 & 0.00577 & 0.07593 & 0.00191 & 0.33039 \\
\hline 147 & Rupali Insurance Company Ltd. & -0.01092 & 0.01173 & 0.10832 & 0.00342 & 0.29158 \\
\hline 148 & National Life Insurance Co Ltd & -0.00689 & 0.00952 & 0.09757 & 0.00178 & 0.18738 \\
\hline 149 & Reliance Insurance Ltd. & -0.00418 & 0.00596 & 0.07720 & 0.00198 & 0.33274 \\
\hline 150 & Purabi Gen. Insurance Company Ltd. & -0.01711 & 0.01308 & 0.11436 & 0.00300 & 0.22962 \\
\hline 151 & Delta Life Insurance Co. Ltd & -0.01578 & 0.03089 & 0.17576 & 0.00374 & 0.12120 \\
\hline 152 & Pragati Insurance Ltd. & -0.00832 & 0.00944 & 0.09715 & 0.00264 & 0.27977 \\
\hline 153 & Sandhani Life Insurance Ltd & -0.01503 & 0.01121 & 0.10589 & 0.00278 & 0.24798 \\
\hline 154 & Prime Insurance Company Limited & -0.00360 & 0.01679 & 0.12958 & 0.00356 & 0.21221 \\
\hline 155 & Pioneer Insurance company Ltd. & -0.01376 & 0.00623 & 0.07894 & 0.00125 & 0.20022 \\
\hline 156 & Mercantile Insurance Co. Ltd. & -0.00224 & 0.00992 & 0.09959 & 0.00261 & 0.26278 \\
\hline 157 & Agrani Insurance Co Ltd. & -0.00354 & 0.01143 & 0.10689 & 0.00241 & 0.21098 \\
\hline 158 & Popular Life Insurance Company Ltd. & -0.00241 & 0.01622 & 0.12737 & 0.00269 & 0.16608 \\
\hline 159 & Fareast Islami Life Insurance Co. Ltd. & -0.00355 & 0.00784 & 0.08855 & 0.00287 & 0.36616 \\
\hline 160 & Meghna Life Insurance Co. Ltd. & -0.00709 & 0.01119 & 0.10580 & 0.00343 & 0.30623 \\
\hline 161 & Nitol Insurance Co. Ltd. & 0.00132 & 0.01083 & 0.10405 & 0.00310 & 0.28661 \\
\hline 162 & Asia Pacific General Insurance Co. Ltd. & -0.00219 & 0.01044 & 0.10216 & 0.00330 & 0.31658 \\
\hline 163 & Sonar Bangla Insurance Ltd. & -0.00769 & 0.00722 & 0.08494 & 0.00213 & 0.29561 \\
\hline 164 & Pragati Life Insurance Ltd. & 0.00530 & 0.01903 & 0.13796 & 0.00222 & 0.11649 \\
\hline 165 & Prime Islami life Insurance Ltd. & -0.00410 & 0.01936 & 0.13915 & 0.00296 & 0.15289 \\
\hline 166 & Paramount Insurance Co. Ltd. & -0.00236 & 0.01021 & 0.10104 & 0.00148 & 0.14503 \\
\hline 167 & City General Insurance Co. Ltd. & -0.00785 & 0.01200 & 0.10953 & 0.00324 & 0.26965 \\
\hline
\end{tabular}


JEMA: Jurnal Ilmiah Bidang Akuntansi dan Manajemen, Vol. 16 No. 1 (2019)

http://riset.unisma.ac.id/index.php/jema (e-ISSN : 2597-4071)

\begin{tabular}{|c|l|c|c|c|c|c|}
\hline $\mathbf{A}$ & \multicolumn{1}{|c|}{$\mathbf{B}$} & $\mathbf{C}$ & $\mathbf{D}$ & $\mathbf{E}$ & $\mathbf{F}$ & $\mathbf{G}$ \\
\hline 168 & Continental Insurance Ltd. & -0.00123 & 0.01732 & 0.13162 & 0.00338 & 0.19511 \\
\hline 169 & Takaful Islami Insurance Ltd. & -0.00403 & 0.01048 & 0.10239 & 0.00129 & 0.12321 \\
\hline 170 & Standard Insurance Ltd. & -0.00292 & 0.01117 & 0.10570 & 0.00188 & 0.16809 \\
\hline 171 & Northern General Insurance Co. Ltd. & -0.00475 & 0.01937 & 0.13918 & 0.00486 & 0.25091 \\
\hline 172 & Republic Insurance Company Ltd. & -0.00391 & 0.01574 & 0.12545 & 0.00329 & 0.20893 \\
\hline 173 & Asia Insurance Co. Ltd. & -0.00481 & 0.01039 & 0.10191 & 0.00276 & 0.26595 \\
\hline 174 & Rupali Life Insurance Co.Ltd. & -0.01071 & 0.01135 & 0.10654 & 0.00219 & 0.19293 \\
\hline 175 & Islami Insurance BD. Ltd. & 0.00309 & 0.00885 & 0.09409 & 0.00270 & 0.30455 \\
\hline 176 & Provati Insurance Company ltd. & -0.00725 & 0.00609 & 0.07802 & 0.00161 & 0.26502 \\
\hline 177 & Dhaka Insurance Co. Ltd. & -0.01203 & 0.00779 & 0.08826 & 0.00272 & 0.34932 \\
\hline 178 & Padma Islami Life Insurance Limited & -0.00215 & 0.01256 & 0.11208 & 0.00295 & 0.23507 \\
\hline $\mathbf{1 7 9}$ & Market Index (DSEX) & $\mathbf{0 . 0 0 6 8 1}$ & $\mathbf{0 . 0 0 2 4 8}$ & $\mathbf{0 . 0 4 9 8 5}$ & $\mathbf{0 . 0 0 2 4 8}$ & $\mathbf{1 . 0 0 0 0 0}$ \\
\hline
\end{tabular}

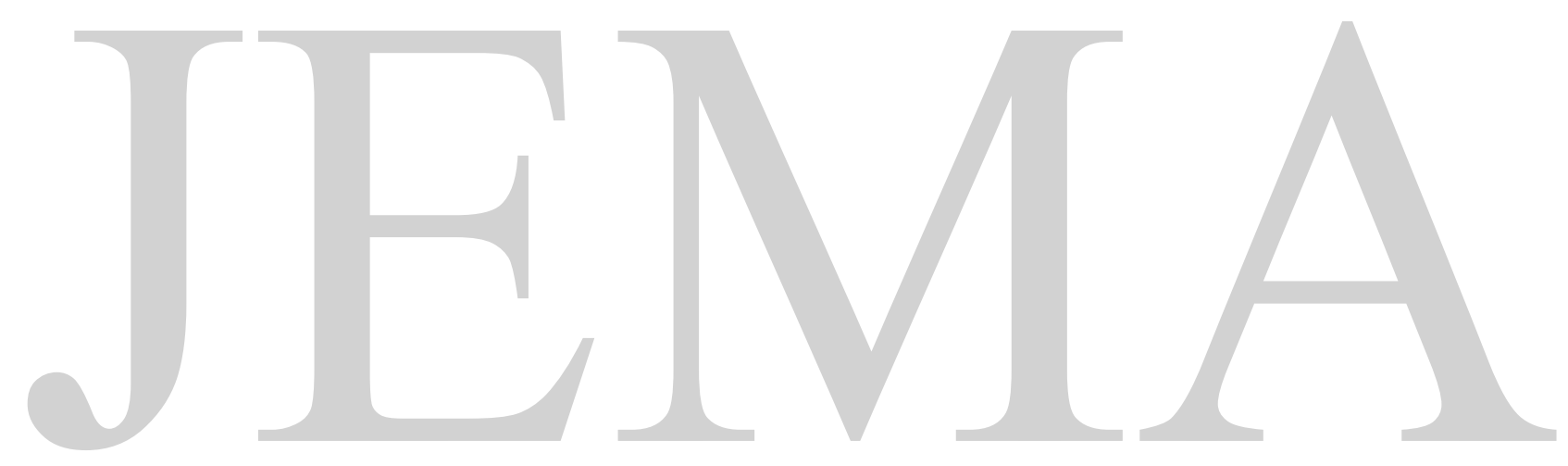


JEMA: Jurnal Ilmiah Bidang Akuntansi dan Manajemen, Vol. 16 No. 1 (2019)

http://riset.unisma.ac.id/index.php/jema (e-ISSN : 2597-4071)

\section{Appendix-B:}

Breakdown of each firm's return and risk into unique and market-related part with

Code A as Stock Number

Code $\mathrm{K}$ as $\boldsymbol{\sigma}_{\boldsymbol{e} i}^{2}$

Code $\mathrm{H}$ as $\boldsymbol{\alpha}_{\boldsymbol{i}}$

Code L as $\boldsymbol{\beta}_{i}^{2} \boldsymbol{\sigma}_{m}^{2}$

Code I as $\boldsymbol{\beta}_{\boldsymbol{i}} \overline{\boldsymbol{R}}_{\boldsymbol{m}}$

Code $\mathrm{M}$ as $\boldsymbol{\sigma}_{\boldsymbol{i}}^{2}$

Code J as $\overline{\boldsymbol{R}}_{\boldsymbol{i}}$

\begin{tabular}{|c|c|c|c|c|c|c|}
\hline $\mathbf{A}$ & $\mathbf{H}$ & $\mathbf{I}$ & $\mathbf{J}$ & $\mathbf{K}$ & $\mathbf{L}$ & $\mathbf{M}$ \\
\hline 1 & -0.00411 & 0.00151 & -0.00260 & 0.01515 & 0.00012 & 0.01528 \\
\hline 2 & 0.00918 & 0.00194 & 0.01113 & 0.01197 & 0.00020 & 0.01217 \\
\hline 3 & -0.00154 & 0.00084 & -0.00070 & 0.02642 & 0.00004 & 0.02645 \\
\hline 4 & 0.00104 & 0.00105 & 0.00209 & 0.01620 & 0.00006 & 0.01626 \\
\hline 5 & -0.00636 & 0.00157 & -0.00479 & 0.01124 & 0.00013 & 0.01138 \\
\hline 6 & -0.00268 & 0.00184 & -0.00084 & 0.00676 & 0.00018 & 0.00694 \\
\hline 7 & -0.00084 & 0.00126 & 0.00042 & 0.01727 & 0.00009 & 0.01736 \\
\hline 8 & 0.00096 & 0.00191 & 0.00287 & 0.01010 & 0.00019 & 0.01029 \\
\hline 9 & -0.00222 & 0.00223 & 0.00001 & 0.00783 & 0.00027 & 0.00809 \\
\hline 10 & 0.00406 & 0.00245 & 0.00650 & 0.00453 & 0.00032 & 0.00485 \\
\hline 11 & 0.00302 & 0.00182 & 0.00484 & 0.01126 & 0.00018 & 0.01143 \\
\hline 12 & -0.00605 & 0.00132 & -0.00472 & 0.00853 & 0.00009 & 0.00863 \\
\hline 13 & 0.00209 & 0.00218 & 0.00426 & 0.00786 & 0.00025 & 0.00812 \\
\hline 14 & -0.00319 & 0.00223 & -0.00096 & 0.01016 & 0.00027 & 0.01042 \\
\hline 15 & -0.00181 & 0.00272 & 0.00091 & 0.00481 & 0.00040 & 0.00520 \\
\hline 16 & 0.00433 & 0.00165 & 0.00599 & 0.00538 & 0.00015 & 0.00553 \\
\hline 17 & 0.00088 & 0.00223 & 0.00311 & 0.00630 & 0.00027 & 0.00657 \\
\hline 18 & 0.00940 & 0.00183 & 0.01123 & 0.00790 & 0.00018 & 0.00808 \\
\hline 19 & -0.00456 & 0.00221 & -0.00235 & 0.00861 & 0.00026 & 0.00887 \\
\hline 20 & -0.00038 & 0.00250 & 0.00212 & 0.00771 & 0.00034 & 0.00805 \\
\hline 21 & 0.00267 & 0.00162 & 0.00429 & 0.00812 & 0.00014 & 0.00826 \\
\hline 22 & 0.00525 & 0.00164 & 0.00689 & 0.00867 & 0.00014 & 0.00882 \\
\hline 23 & -0.00474 & 0.00214 & -0.00260 & 0.00621 & 0.00024 & 0.00646 \\
\hline 24 & -0.00063 & 0.00194 & 0.00131 & 0.00545 & 0.00020 & 0.00565 \\
\hline 25 & 0.01884 & 0.00146 & 0.02030 & 0.00959 & 0.00011 & 0.00971 \\
\hline 26 & 0.00404 & 0.00149 & 0.00553 & 0.00898 & 0.00012 & 0.00910 \\
\hline 27 & -0.00180 & 0.00188 & 0.00008 & 0.00835 & 0.00019 & 0.00854 \\
\hline 28 & 0.01301 & 0.00156 & 0.01457 & 0.01393 & 0.00013 & 0.01406 \\
\hline 29 & -0.00284 & 0.00199 & -0.00085 & 0.00898 & 0.00021 & 0.00919 \\
\hline 30 & 0.00273 & 0.00188 & 0.00461 & 0.01720 & 0.00019 & 0.01739 \\
\hline 31 & -0.00434 & 0.00212 & -0.00221 & 0.01133 & 0.00024 & 0.01157 \\
\hline 32 & -0.00282 & 0.00274 & -0.00008 & 0.00775 & 0.00040 & 0.00815 \\
\hline 33 & 0.00262 & 0.00155 & 0.00417 & 0.01465 & 0.00013 & 0.01478 \\
\hline 34 & -0.00002 & 0.00186 & 0.00183 & 0.01304 & 0.00018 & 0.01323 \\
\hline 35 & 0.00341 & 0.00128 & 0.00469 & 0.02961 & 0.00009 & 0.02970 \\
\hline
\end{tabular}

JEMA: Jurnal Ilmiah Bidang Akuntansi dan Manajemen is licensed under a

Creative Commons Attribution 4.0 International License 
JEMA: Jurnal Ilmiah Bidang Akuntansi dan Manajemen, Vol. 16 No. 1 (2019) http://riset.unisma.ac.id/index.php/jema (e-ISSN : 2597-4071)

\begin{tabular}{|c|c|c|c|c|c|c|}
\hline $\mathbf{A}$ & H & I & $\mathbf{J}$ & $\mathbf{K}$ & $\mathbf{L}$ & $\mathbf{M}$ \\
\hline 36 & 0.01754 & 0.00154 & 0.01908 & 0.01287 & 0.00013 & 0.01299 \\
\hline 37 & -0.00065 & 0.00132 & 0.00067 & 0.02091 & 0.00009 & 0.02101 \\
\hline 38 & 0.00213 & 0.00158 & 0.00371 & 0.01993 & 0.00013 & 0.02006 \\
\hline 39 & 0.00515 & 0.00168 & 0.00683 & 0.01990 & 0.00015 & 0.02006 \\
\hline 40 & 0.00137 & 0.00145 & 0.00281 & 0.01682 & 0.00011 & 0.01693 \\
\hline 41 & 0.00376 & 0.00102 & 0.00478 & 0.02550 & 0.00006 & 0.02556 \\
\hline 42 & -0.00127 & 0.00193 & 0.00066 & 0.01302 & 0.00020 & 0.01322 \\
\hline 43 & 0.01195 & 0.00110 & 0.01305 & 0.01271 & 0.00006 & 0.01277 \\
\hline 44 & 0.03117 & 0.00047 & 0.03165 & 0.01616 & 0.00001 & 0.01617 \\
\hline 45 & 0.03505 & -0.00031 & 0.03474 & 0.01998 & 0.00001 & 0.01998 \\
\hline 46 & 0.00716 & 0.00156 & 0.00873 & 0.01421 & 0.00013 & 0.01435 \\
\hline 47 & 0.00140 & 0.00139 & 0.00279 & 0.01158 & 0.00010 & 0.01168 \\
\hline 48 & 0.01799 & 0.00112 & 0.01912 & 0.01975 & 0.00007 & 0.01982 \\
\hline 49 & 0.04887 & 0.00005 & 0.04892 & 0.04320 & 0.00000 & 0.04320 \\
\hline 50 & 0.02992 & 0.00087 & 0.03079 & 0.02578 & 0.00004 & 0.02582 \\
\hline 51 & 0.03357 & -0.00015 & 0.03342 & 0.02169 & 0.00000 & 0.02169 \\
\hline 52 & 0.01400 & 0.00126 & 0.01526 & 0.00610 & 0.00009 & 0.00618 \\
\hline 53 & -0.00595 & 0.00227 & -0.00368 & 0.00802 & 0.00028 & 0.00830 \\
\hline 54 & 0.01485 & 0.00126 & 0.01611 & 0.00976 & 0.00008 & 0.00984 \\
\hline 55 & 0.00514 & 0.00205 & 0.00718 & 0.01416 & 0.00022 & 0.01438 \\
\hline 56 & -0.00143 & 0.00231 & 0.00088 & 0.01088 & 0.00028 & 0.01116 \\
\hline 57 & 0.00085 & 0.00110 & 0.00194 & 0.01367 & 0.00006 & 0.01373 \\
\hline 58 & 0.00141 & 0.00185 & 0.00326 & 0.01549 & 0.00018 & 0.01568 \\
\hline 59 & 0.02113 & 0.00093 & 0.02206 & 0.01160 & 0.00005 & 0.01165 \\
\hline 60 & 0.02229 & 0.00082 & 0.02311 & 0.01620 & 0.00004 & 0.01623 \\
\hline 61 & 0.02508 & 0.00046 & 0.02554 & 0.00555 & 0.00001 & 0.00556 \\
\hline 62 & 0.03411 & -0.00033 & 0.03379 & 0.04662 & 0.00001 & 0.04662 \\
\hline 63 & -0.00307 & 0.00043 & -0.00264 & 0.00488 & 0.00001 & 0.00489 \\
\hline 64 & 0.01347 & 0.00072 & 0.01419 & 0.01047 & 0.00003 & 0.01050 \\
\hline 65 & 0.00078 & 0.00139 & 0.00218 & 0.01537 & 0.00010 & 0.01547 \\
\hline 66 & -0.00154 & 0.00132 & -0.00021 & 0.01664 & 0.00009 & 0.01674 \\
\hline 67 & 0.01606 & 0.00140 & 0.01745 & 0.00800 & 0.00010 & 0.00811 \\
\hline 68 & 0.00888 & 0.00140 & 0.01029 & 0.01495 & 0.00011 & 0.01505 \\
\hline 69 & 0.04170 & -0.00012 & 0.04159 & 0.05485 & 0.00000 & 0.05485 \\
\hline 70 & -0.00337 & 0.00249 & -0.00089 & 0.01066 & 0.00033 & 0.01099 \\
\hline 71 & -0.00739 & 0.00191 & -0.00548 & 0.00714 & 0.00020 & 0.00734 \\
\hline 72 & 0.00102 & 0.00181 & 0.00283 & 0.00810 & 0.00018 & 0.00827 \\
\hline 73 & 0.00373 & 0.00146 & 0.00520 & 0.00635 & 0.00011 & 0.00647 \\
\hline 74 & 0.00556 & 0.00131 & 0.00688 & 0.00936 & 0.00009 & 0.00945 \\
\hline 75 & -0.00827 & 0.00279 & -0.00547 & 0.00332 & 0.00042 & 0.00374 \\
\hline 76 & 0.00444 & 0.00186 & 0.00630 & 0.00853 & 0.00018 & 0.00871 \\
\hline 77 & 0.00340 & 0.00197 & 0.00537 & 0.01185 & 0.00021 & 0.01206 \\
\hline 78 & 0.00665 & 0.00166 & 0.00831 & 0.00907 & 0.00015 & 0.00921 \\
\hline 79 & -0.00960 & 0.00249 & -0.00711 & 0.00936 & 0.00033 & 0.00969 \\
\hline
\end{tabular}


JEMA: Jurnal Ilmiah Bidang Akuntansi dan Manajemen, Vol. 16 No. 1 (2019) http://riset.unisma.ac.id/index.php/jema (e-ISSN : 2597-4071)

\begin{tabular}{|c|c|c|c|c|c|c|}
\hline $\mathbf{A}$ & $\mathbf{H}$ & I & $\mathbf{J}$ & $\mathbf{K}$ & $\mathbf{L}$ & $\mathbf{M}$ \\
\hline 80 & 0.08231 & -0.00004 & 0.08227 & 0.07274 & 0.00000 & 0.07274 \\
\hline 81 & 0.01664 & 0.00055 & 0.01719 & 0.01274 & 0.00002 & 0.01276 \\
\hline 82 & 0.02298 & 0.00022 & 0.02320 & 0.02898 & 0.00000 & 0.02898 \\
\hline 83 & 0.02575 & -0.00007 & 0.02568 & 0.03174 & 0.00000 & 0.03174 \\
\hline 84 & 0.02295 & 0.00066 & 0.02361 & 0.02929 & 0.00002 & 0.02932 \\
\hline 85 & -0.00656 & 0.00234 & -0.00421 & 0.00605 & 0.00029 & 0.00634 \\
\hline 86 & 0.05449 & -0.00011 & 0.05439 & 0.05976 & 0.00000 & 0.05976 \\
\hline 87 & 0.01531 & 0.00095 & 0.01626 & 0.01206 & 0.00005 & 0.01211 \\
\hline 88 & -0.01692 & 0.00097 & -0.01595 & 0.01618 & 0.00005 & 0.01623 \\
\hline 89 & 0.00331 & 0.00163 & 0.00495 & 0.00894 & 0.00014 & 0.00908 \\
\hline 90 & 0.01246 & 0.00053 & 0.01299 & 0.01567 & 0.00002 & 0.01568 \\
\hline 91 & 0.00643 & 0.00119 & 0.00762 & 0.01752 & 0.00008 & 0.01759 \\
\hline 92 & -0.00670 & 0.00092 & -0.00579 & 0.02216 & 0.00005 & 0.02221 \\
\hline 93 & -0.01179 & 0.00244 & -0.00935 & 0.00265 & 0.00032 & 0.00297 \\
\hline 94 & -0.01039 & 0.00068 & -0.00971 & 0.01272 & 0.00002 & 0.01274 \\
\hline 95 & 0.00108 & 0.00141 & 0.00250 & 0.00875 & 0.00011 & 0.00885 \\
\hline 96 & -0.00728 & 0.00090 & -0.00638 & 0.01279 & 0.00004 & 0.01283 \\
\hline 97 & -0.01111 & 0.00206 & -0.00905 & 0.00515 & 0.00023 & 0.00538 \\
\hline 98 & -0.01612 & 0.00131 & -0.01481 & 0.01294 & 0.00009 & 0.01303 \\
\hline 99 & -0.00644 & 0.00146 & -0.00498 & 0.00446 & 0.00011 & 0.00458 \\
\hline 100 & 0.01553 & 0.00029 & 0.01582 & 0.01131 & 0.00000 & 0.01131 \\
\hline 101 & 0.01126 & 0.00208 & 0.01334 & 0.00829 & 0.00023 & 0.00852 \\
\hline 102 & 0.02034 & 0.00093 & 0.02127 & 0.00838 & 0.00005 & 0.00843 \\
\hline 103 & 0.02173 & 0.00104 & 0.02278 & 0.01216 & 0.00006 & 0.01222 \\
\hline 104 & 0.01257 & 0.00057 & 0.01314 & 0.00879 & 0.00002 & 0.00881 \\
\hline 105 & 0.01688 & 0.00095 & 0.01783 & 0.00938 & 0.00005 & 0.00943 \\
\hline 106 & 0.02580 & 0.00034 & 0.02614 & 0.00944 & 0.00001 & 0.00944 \\
\hline 107 & 0.01749 & 0.00009 & 0.01758 & 0.01209 & 0.00000 & 0.01209 \\
\hline 108 & 0.02234 & 0.00064 & 0.02298 & 0.01388 & 0.00002 & 0.01390 \\
\hline 109 & 0.02660 & 0.00018 & 0.02678 & 0.02097 & 0.00000 & 0.02097 \\
\hline 110 & 0.00743 & 0.00117 & 0.00861 & 0.01102 & 0.00007 & 0.01110 \\
\hline 111 & 0.00953 & 0.00214 & 0.01167 & 0.00366 & 0.00025 & 0.00390 \\
\hline 112 & -0.01335 & 0.00143 & -0.01192 & 0.01362 & 0.00011 & 0.01373 \\
\hline 113 & 0.02092 & 0.00117 & 0.02209 & 0.02136 & 0.00007 & 0.02144 \\
\hline 114 & 0.02084 & 0.00055 & 0.02138 & 0.00941 & 0.00002 & 0.00943 \\
\hline 115 & -0.01037 & 0.00176 & -0.00861 & 0.00910 & 0.00017 & 0.00926 \\
\hline 116 & 0.00768 & 0.00091 & 0.00859 & 0.00941 & 0.00004 & 0.00945 \\
\hline 117 & 0.00366 & 0.00196 & 0.00561 & 0.00826 & 0.00020 & 0.00847 \\
\hline 118 & 0.01149 & 0.00104 & 0.01253 & 0.02848 & 0.00006 & 0.02854 \\
\hline 119 & 0.00594 & 0.00063 & 0.00657 & 0.04852 & 0.00002 & 0.04854 \\
\hline 120 & 0.00904 & 0.00156 & 0.01060 & 0.00903 & 0.00013 & 0.00916 \\
\hline 121 & 0.00883 & 0.00218 & 0.01100 & 0.01084 & 0.00025 & 0.01109 \\
\hline 122 & 0.00422 & 0.00139 & 0.00562 & 0.01816 & 0.00010 & 0.01827 \\
\hline 123 & 0.01503 & 0.00120 & 0.01623 & 0.01631 & 0.00008 & 0.01639 \\
\hline
\end{tabular}


JEMA: Jurnal Ilmiah Bidang Akuntansi dan Manajemen, Vol. 16 No. 1 (2019) http://riset.unisma.ac.id/index.php/jema (e-ISSN : 2597-4071)

\begin{tabular}{|c|c|c|c|c|c|c|}
\hline $\mathbf{A}$ & $\mathbf{H}$ & I & $\mathbf{J}$ & $\mathbf{K}$ & $\mathbf{L}$ & $\mathbf{M}$ \\
\hline 124 & -0.00094 & 0.00256 & 0.00162 & 0.00491 & 0.00035 & 0.00526 \\
\hline 125 & 0.01391 & 0.00056 & 0.01447 & 0.02434 & 0.00002 & 0.02435 \\
\hline 126 & 0.00322 & 0.00148 & 0.00470 & 0.01314 & 0.00012 & 0.01326 \\
\hline 127 & -0.00098 & 0.00233 & 0.00136 & 0.00919 & 0.00029 & 0.00948 \\
\hline 128 & 0.01745 & 0.00067 & 0.01811 & 0.01383 & 0.00002 & 0.01386 \\
\hline 129 & 0.00389 & 0.00170 & 0.00559 & 0.01414 & 0.00015 & 0.01429 \\
\hline 130 & 0.04012 & 0.00022 & 0.04033 & 0.07562 & 0.00000 & 0.07562 \\
\hline 131 & 0.01481 & 0.00154 & 0.01635 & 0.01421 & 0.00013 & 0.01434 \\
\hline 132 & 0.01425 & 0.00151 & 0.01575 & 0.00546 & 0.00012 & 0.00558 \\
\hline 133 & 0.00935 & 0.00140 & 0.01076 & 0.01109 & 0.00011 & 0.01119 \\
\hline 134 & 0.04277 & 0.00006 & 0.04283 & 0.08907 & 0.00000 & 0.08907 \\
\hline 135 & 0.03522 & 0.00033 & 0.03555 & 0.02916 & 0.00001 & 0.02916 \\
\hline 136 & -0.00077 & 0.00171 & 0.00094 & 0.01020 & 0.00016 & 0.01036 \\
\hline 137 & 0.00010 & 0.00194 & 0.00204 & 0.01258 & 0.00020 & 0.01278 \\
\hline 138 & -0.00369 & 0.00186 & -0.00183 & 0.01353 & 0.00019 & 0.01372 \\
\hline 139 & -0.00091 & 0.00153 & 0.00062 & 0.00875 & 0.00013 & 0.00888 \\
\hline 140 & -0.00317 & 0.00181 & -0.00136 & 0.01520 & 0.00018 & 0.01537 \\
\hline 141 & -0.00458 & 0.00243 & -0.00215 & 0.00591 & 0.00032 & 0.00622 \\
\hline 142 & -0.00545 & 0.00271 & -0.00274 & 0.00592 & 0.00039 & 0.00632 \\
\hline 143 & -0.01126 & 0.00163 & -0.00962 & 0.01083 & 0.00014 & 0.01097 \\
\hline 144 & -0.01473 & 0.00212 & -0.01261 & 0.00971 & 0.00024 & 0.00995 \\
\hline 145 & -0.00716 & 0.00143 & -0.00573 & 0.00652 & 0.00011 & 0.00663 \\
\hline 146 & -0.01078 & 0.00225 & -0.00853 & 0.00549 & 0.00027 & 0.00577 \\
\hline 147 & -0.01291 & 0.00199 & -0.01092 & 0.01152 & 0.00021 & 0.01173 \\
\hline 148 & -0.00817 & 0.00128 & -0.00689 & 0.00943 & 0.00009 & 0.00952 \\
\hline 149 & -0.00645 & 0.00227 & -0.00418 & 0.00569 & 0.00028 & 0.00596 \\
\hline 150 & -0.01867 & 0.00156 & -0.01711 & 0.01295 & 0.00013 & 0.01308 \\
\hline 151 & -0.01661 & 0.00083 & -0.01578 & 0.03086 & 0.00004 & 0.03089 \\
\hline 152 & -0.01023 & 0.00191 & -0.00832 & 0.00924 & 0.00019 & 0.00944 \\
\hline 153 & -0.01672 & 0.00169 & -0.01503 & 0.01106 & 0.00015 & 0.01121 \\
\hline 154 & -0.00504 & 0.00145 & -0.00360 & 0.01668 & 0.00011 & 0.01679 \\
\hline 155 & -0.01512 & 0.00136 & -0.01376 & 0.00613 & 0.00010 & 0.00623 \\
\hline 156 & -0.00403 & 0.00179 & -0.00224 & 0.00975 & 0.00017 & 0.00992 \\
\hline 157 & -0.00497 & 0.00144 & -0.00354 & 0.01131 & 0.00011 & 0.01143 \\
\hline 158 & -0.00354 & 0.00113 & -0.00241 & 0.01616 & 0.00007 & 0.01622 \\
\hline 159 & -0.00605 & 0.00249 & -0.00355 & 0.00751 & 0.00033 & 0.00784 \\
\hline 160 & -0.00918 & 0.00209 & -0.00709 & 0.01096 & 0.00023 & 0.01119 \\
\hline 161 & -0.00063 & 0.00195 & 0.00132 & 0.01062 & 0.00020 & 0.01083 \\
\hline 162 & -0.00435 & 0.00216 & -0.00219 & 0.01019 & 0.00025 & 0.01044 \\
\hline 163 & -0.00970 & 0.00201 & -0.00769 & 0.00700 & 0.00022 & 0.00722 \\
\hline 164 & 0.00451 & 0.00079 & 0.00530 & 0.01900 & 0.00003 & 0.01903 \\
\hline 165 & -0.00514 & 0.00104 & -0.00410 & 0.01930 & 0.00006 & 0.01936 \\
\hline 166 & -0.00335 & 0.00099 & -0.00236 & 0.01016 & 0.00005 & 0.01021 \\
\hline 167 & -0.00969 & 0.00184 & -0.00785 & 0.01182 & 0.00018 & 0.01200 \\
\hline
\end{tabular}

JEMA: Jurnal Ilmiah Bidang Akuntansi dan Manajemen is licensed under a Creative Commons Attribution 4.0 International License 
JEMA: Jurnal Ilmiah Bidang Akuntansi dan Manajemen, Vol. 16 No. 1 (2019) http://riset.unisma.ac.id/index.php/jema (e-ISSN : 2597-4071)

\begin{tabular}{|c|c|c|c|c|c|c|}
\hline $\mathbf{A}$ & $\mathbf{H}$ & $\mathbf{I}$ & $\mathbf{J}$ & $\mathbf{K}$ & $\mathbf{L}$ & $\mathbf{M}$ \\
\hline 168 & -0.00256 & 0.00133 & -0.00123 & 0.01723 & 0.00009 & 0.01732 \\
\hline 169 & -0.00487 & 0.00084 & -0.00403 & 0.01045 & 0.00004 & 0.01048 \\
\hline 170 & -0.00406 & 0.00115 & -0.00292 & 0.01110 & 0.00007 & 0.01117 \\
\hline 171 & -0.00646 & 0.00171 & -0.00475 & 0.01921 & 0.00016 & 0.01937 \\
\hline 172 & -0.00534 & 0.00142 & -0.00391 & 0.01563 & 0.00011 & 0.01574 \\
\hline 173 & -0.00662 & 0.00181 & -0.00481 & 0.01021 & 0.00018 & 0.01039 \\
\hline 174 & -0.01202 & 0.00131 & -0.01071 & 0.01126 & 0.00009 & 0.01135 \\
\hline 175 & 0.00102 & 0.00207 & 0.00309 & 0.00862 & 0.00023 & 0.00885 \\
\hline 176 & -0.00906 & 0.00181 & -0.00725 & 0.00591 & 0.00017 & 0.00609 \\
\hline 177 & -0.01440 & 0.00238 & -0.01203 & 0.00749 & 0.00030 & 0.00779 \\
\hline 178 & -0.00375 & 0.00160 & -0.00215 & 0.01242 & 0.00014 & 0.01256 \\
\hline
\end{tabular}

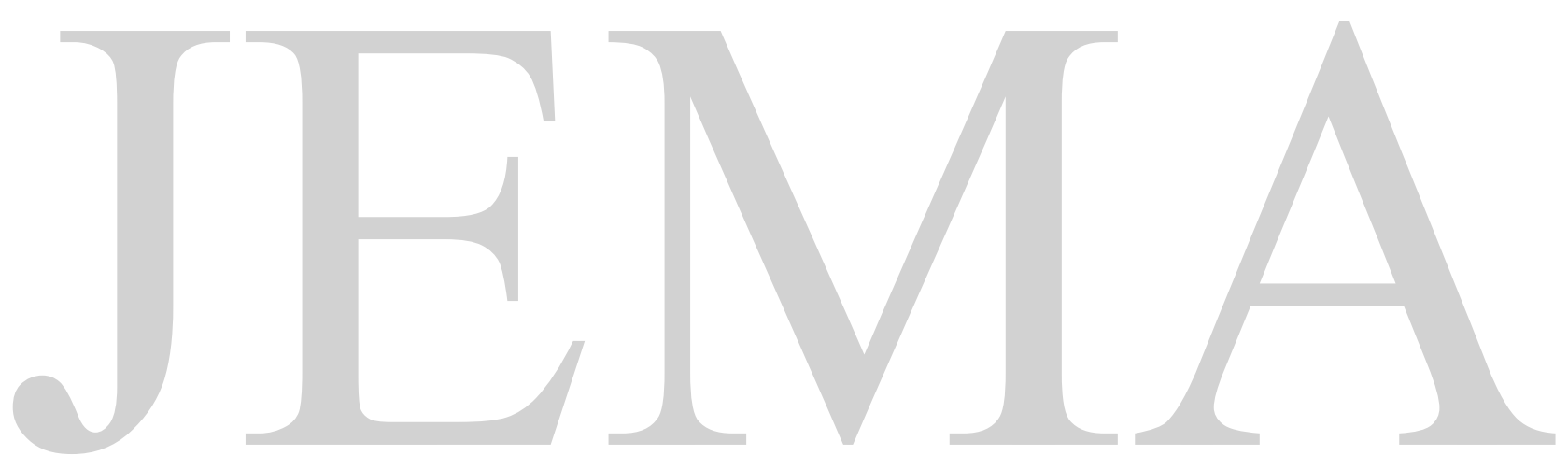


JEMA: Jurnal Ilmiah Bidang Akuntansi dan Manajemen, Vol. 16 No. 1 (2019)

http://riset.unisma.ac.id/index.php/jema (e-ISSN : 2597-4071)

\section{Appendix-C:}

Ranking of stocks according to their excess return-to-beta ratio with

Code $\mathrm{N}$ as Rank

Code $\mathrm{Q}$ as $\left(\overline{\boldsymbol{R}}_{\boldsymbol{i}}-\boldsymbol{R}_{\boldsymbol{f}}\right)$

Code $\mathrm{O}$ as Company Name

Code R as $\boldsymbol{\beta}_{\boldsymbol{i}}$

Code P as $\left(\overline{\boldsymbol{R}}_{\boldsymbol{i}}\right)$

Code $S$ as $\frac{\overline{\boldsymbol{R}}_{\boldsymbol{i}}-\boldsymbol{R}_{\boldsymbol{f}}}{\boldsymbol{\beta}_{\boldsymbol{i}}}$

\begin{tabular}{|c|c|c|c|c|c|}
\hline $\mathbf{N}$ & $\mathbf{O}$ & $\mathbf{P}$ & $\mathbf{Q}$ & $\mathbf{R}$ & $\mathbf{S}$ \\
\hline 1 & Renwick Jajneswar \& Co (Bd) Ltd. & 0.04892 & 0.04413 & 0.00714 & 6.18333 \\
\hline 2 & Legacy Footwear Ltd. & 0.04283 & 0.03805 & 0.00902 & 4.21675 \\
\hline 3 & Grameenphone Ltd. & 0.04033 & 0.03555 & 0.03157 & 1.12589 \\
\hline 4 & Kohinoor Chemicals Company (Bangladesh) Ltd. & 0.01758 & 0.01279 & 0.01278 & 1.00118 \\
\hline 5 & Libra Infusions Limited & 0.02678 & 0.02200 & 0.02627 & 0.83736 \\
\hline 6 & Monno Ceramic Industries Ltd. & 0.03555 & 0.03077 & 0.04893 & 0.62871 \\
\hline 7 & Al-Haj Textile Mills Limited & 0.02320 & 0.01841 & 0.03196 & 0.57611 \\
\hline 8 & Pharma Aids Ltd. & 0.02614 & 0.02135 & 0.05015 & 0.42578 \\
\hline 9 & Eastern Cables Ltd. & 0.03165 & 0.02686 & 0.06957 & 0.38610 \\
\hline 10 & British American Tobacco Bangladesh Company Limited & 0.02554 & 0.02076 & 0.06771 & 0.30655 \\
\hline 11 & Ambee Pharma Ltd. & 0.01582 & 0.01104 & 0.04265 & 0.25884 \\
\hline 12 & Marico Bangladesh Ltd. & 0.02138 & 0.01660 & 0.08022 & 0.20693 \\
\hline 13 & National tubes Ltd. & 0.03079 & 0.02600 & 0.12802 & 0.20314 \\
\hline 14 & Rahim Textile Mills Ltd. & 0.02361 & 0.01883 & 0.09635 & 0.19539 \\
\hline 15 & The IBN SINA Pharmaceutical Industry Ltd. & 0.02298 & 0.01819 & 0.09345 & 0.19466 \\
\hline 16 & Sonali Aansh Industries Limited & 0.01719 & 0.01241 & 0.08073 & 0.15372 \\
\hline 17 & Apex Foods Limited & 0.02311 & 0.01833 & 0.11994 & 0.15279 \\
\hline 18 & Daffodil Computers Ltd. & 0.01811 & 0.01333 & 0.09811 & 0.13586 \\
\hline 19 & Olympic Industries Limited & 0.02206 & 0.01727 & 0.13604 & 0.12698 \\
\hline 20 & GlaxoSmithKline(GSK) Bangladesh Limited & 0.02127 & 0.01648 & 0.13605 & 0.12113 \\
\hline 21 & BDCOM Online Ltd. & 0.01447 & 0.00968 & 0.08163 & 0.11864 \\
\hline 22 & ACI Limited. & 0.02278 & 0.01799 & 0.15302 & 0.11757 \\
\hline 23 & Anlima Yarn Dyeing Ltd. & 0.01299 & 0.00821 & 0.07836 & 0.10474 \\
\hline 24 & ACI Formulations Ltd. & 0.02209 & 0.01730 & 0.17129 & 0.10103 \\
\hline 25 & Renata Ltd. & 0.01314 & 0.00836 & 0.08427 & 0.09916 \\
\hline 26 & Reckitt Benckiser (Bd.)Ltd. & 0.01783 & 0.01305 & 0.13937 & 0.09361 \\
\hline 27 & Agricultural Marketing Company Ltd. (Pran) & 0.01419 & 0.00940 & 0.10499 & 0.08956 \\
\hline 28 & Quasem Drycells Ltd. & 0.01912 & 0.01433 & 0.16512 & 0.08681 \\
\hline 29 & Apex Spinning \& Knitting Mills Limited & 0.01626 & 0.01148 & 0.14013 & 0.08192 \\
\hline 30 & BRAC Bank Ltd. & 0.02030 & 0.01552 & 0.21499 & 0.07219 \\
\hline 31 & Lafarge Surma Cement Ltd. & 0.01623 & 0.01145 & 0.17688 & 0.06473 \\
\hline 32 & IPDC Finance Limited & 0.01908 & 0.01430 & 0.22657 & 0.06310 \\
\hline 33 & Linde Bangladesh Limited & 0.01745 & 0.01267 & 0.20492 & 0.06182 \\
\hline 34 & National Polymer Industries Ltd & 0.01611 & 0.01132 & 0.18475 & 0.06129 \\
\hline 35 & Rangpur Foundry Ltd. & 0.01526 & 0.01047 & 0.18526 & 0.05653 \\
\hline 36 & Bangladesh Lamps Limited & 0.01305 & 0.00827 & 0.16122 & 0.05127 \\
\hline
\end{tabular}

JEMA: Jurnal Ilmiah Bidang Akuntansi dan Manajemen is licensed under a

Creative Commons Attribution 4.0 International License 
JEMA: Jurnal Ilmiah Bidang Akuntansi dan Manajemen, Vol. 16 No. 1 (2019)

http://riset.unisma.ac.id/index.php/jema (e-ISSN : 2597-4071)

\begin{tabular}{|c|c|c|c|c|c|}
\hline $\mathbf{N}$ & $\mathbf{O}$ & $\mathbf{P}$ & $\mathbf{Q}$ & $\mathbf{R}$ & $\mathbf{S}$ \\
\hline 37 & Apex Tannery Limited & 0.01635 & 0.01157 & 0.22622 & 0.05115 \\
\hline 38 & Summit Alliance Port Limited & 0.01253 & 0.00774 & 0.15249 & 0.05079 \\
\hline 39 & Bata Shoe Company (Bangladesh) Limited & 0.01575 & 0.01097 & 0.22110 & 0.04960 \\
\hline 40 & Trust Bank Ltd. & 0.01457 & 0.00979 & 0.22960 & 0.04263 \\
\hline 41 & Apex Footwear Limited & 0.01076 & 0.00597 & 0.20568 & 0.02903 \\
\hline 42 & Samorita Hospital Ltd. & 0.00859 & 0.00381 & 0.13350 & 0.02853 \\
\hline 43 & Beximco Pharmaceuticals Ltd. & 0.01334 & 0.00856 & 0.30569 & 0.02800 \\
\hline 44 & Padma Oil Co.Ltd. & 0.01029 & 0.00550 & 0.20622 & 0.02668 \\
\hline 45 & Heidelberg Cement Bangladesh Ltd. & 0.01060 & 0.00582 & 0.22901 & 0.02540 \\
\hline 46 & Mutual Trust Bank Ltd. & 0.01123 & 0.00645 & 0.26881 & 0.02398 \\
\hline 47 & The City Bank Ltd. & 0.01113 & 0.00634 & 0.28493 & 0.02226 \\
\hline 48 & Orion Infusion Ltd. & 0.00861 & 0.00382 & 0.17229 & 0.02219 \\
\hline 49 & Square Pharmaceuticals Ltd. & 0.01167 & 0.00689 & 0.31474 & 0.02188 \\
\hline 50 & Confidence Cement Ltd. & 0.01100 & 0.00622 & 0.31933 & 0.01947 \\
\hline 51 & Unique Hotel \& Resorts Limited & 0.00657 & 0.00179 & 0.09248 & 0.01932 \\
\hline 52 & Singer Bangladesh Ltd. & 0.00873 & 0.00394 & 0.22916 & 0.01720 \\
\hline 53 & H.R. Textile Ltd. & 0.00762 & 0.00284 & 0.17462 & 0.01624 \\
\hline 54 & MJL Bangladesh Limited & 0.00831 & 0.00352 & 0.24299 & 0.01450 \\
\hline 55 & Meghna Petroleum Ltd. & 0.00688 & 0.00209 & 0.19282 & 0.01085 \\
\hline 56 & Mercantile Bank Ltd. & 0.00689 & 0.00211 & 0.24136 & 0.00874 \\
\hline 57 & Phoenix Finance and Investments Ltd. & 0.00683 & 0.00205 & 0.24701 & 0.00830 \\
\hline 58 & BSRM Steels Limited & 0.00718 & 0.00240 & 0.30040 & 0.00798 \\
\hline 59 & Khulna Power Company Ltd. & 0.00630 & 0.00151 & 0.27241 & 0.00555 \\
\hline 60 & Social Islami Bank Ltd. & 0.00599 & 0.00120 & 0.24267 & 0.00495 \\
\hline 61 & Eastern Bank Ltd. & 0.00650 & 0.00172 & 0.35953 & 0.00479 \\
\hline 62 & Pragati Life Insurance Ltd. & 0.00530 & 0.00052 & 0.11649 & 0.00443 \\
\hline 63 & Meghna Cement Mills Ltd & 0.00562 & 0.00084 & 0.20473 & 0.00408 \\
\hline 64 & Shahjalal Islami Bank Ltd. & 0.00553 & 0.00074 & 0.21899 & 0.00339 \\
\hline 65 & aamra technologies limited & 0.00559 & 0.00081 & 0.24921 & 0.00324 \\
\hline 66 & Eastern Housing Limited & 0.00561 & 0.00083 & 0.28701 & 0.00289 \\
\hline 67 & Baraka Power Limited & 0.00537 & 0.00059 & 0.28984 & 0.00203 \\
\hline 68 & Jamuna Oil Com. Ltd. & 0.00520 & 0.00041 & 0.21505 & 0.00192 \\
\hline 69 & Prime Textile Spinning Mills Ltd. & 0.00495 & 0.00016 & 0.23979 & 0.00067 \\
\hline 70 & Al-Arafah Islami Bank Ltd. & 0.00484 & 0.00005 & 0.26704 & 0.00019 \\
\hline 71 & GSP Finance Company (Bangladesh) Limited & 0.00478 & 0.00000 & 0.15041 & -0.00002 \\
\hline 72 & Intech Limited & 0.00470 & -0.00008 & 0.21731 & -0.00038 \\
\hline 73 & LankaBangla Finance Ltd. & 0.00469 & -0.00009 & 0.18862 & -0.00050 \\
\hline 74 & IDLC Finance Limited & 0.00461 & -0.00018 & 0.27608 & -0.00064 \\
\hline 75 & Southeast Bank Ltd. & 0.00426 & -0.00052 & 0.31930 & -0.00164 \\
\hline 76 & Bank Asia Ltd. & 0.00429 & -0.00050 & 0.23776 & -0.00209 \\
\hline 77 & Premier Leasing \& Finance Limited. & 0.00417 & -0.00061 & 0.22791 & -0.00268 \\
\hline 78 & Bangladesh Finance and Investment Co. Ltd. & 0.00371 & -0.00107 & 0.23210 & -0.00461 \\
\hline 79 & Dutch-Bangla Bank Ltd. & 0.00311 & -0.00167 & 0.32799 & -0.00511 \\
\hline 80 & Islami Insurance BD. Ltd. & 0.00309 & -0.00169 & 0.30455 & -0.00556 \\
\hline
\end{tabular}


JEMA: Jurnal Ilmiah Bidang Akuntansi dan Manajemen, Vol. 16 No. 1 (2019)

http://riset.unisma.ac.id/index.php/jema (e-ISSN : 2597-4071)

\begin{tabular}{|c|c|c|c|c|c|}
\hline $\mathbf{N}$ & $\mathbf{O}$ & $\mathbf{P}$ & $\mathbf{Q}$ & $\mathbf{R}$ & $\mathbf{S}$ \\
\hline 81 & GPH Ispat Ltd. & 0.00326 & -0.00152 & 0.27131 & -0.00562 \\
\hline 82 & United Commercial Bank Ltd. & 0.00287 & -0.00191 & 0.28005 & -0.00684 \\
\hline 83 & One Bank Limited & 0.00212 & -0.00266 & 0.36771 & -0.00724 \\
\hline 84 & Power Grid Company of Bangladesh Ltd. & 0.00283 & -0.00195 & 0.26586 & -0.00734 \\
\hline 85 & M.I. Cement Factory Limited & 0.00162 & -0.00316 & 0.37557 & -0.00842 \\
\hline 86 & Bay Leasing \& Investment Ltd. & 0.00281 & -0.00197 & 0.21247 & -0.00928 \\
\hline 87 & RAK Ceramics (BD) Ltd. & 0.00204 & -0.00274 & 0.28468 & -0.00964 \\
\hline 88 & National Credit and Commerce Bank Ltd. & 0.00091 & -0.00387 & 0.39944 & -0.00969 \\
\hline 89 & Atlas Bangladesh Ltd. & 0.00279 & -0.00199 & 0.20380 & -0.00979 \\
\hline 90 & Agni Systems Ltd. & 0.00136 & -0.00343 & 0.34223 & -0.01002 \\
\hline 91 & Islamic Finance \& Investment Ltd. & 0.00183 & -0.00295 & 0.27282 & -0.01081 \\
\hline 92 & Malek Spinning Mills Ltd. & 0.00250 & -0.00229 & 0.20731 & -0.01104 \\
\hline 93 & Navana CNG Limited & 0.00088 & -0.00390 & 0.33858 & -0.01153 \\
\hline 94 & Nitol Insurance Co. Ltd. & 0.00132 & -0.00346 & 0.28661 & -0.01208 \\
\hline 95 & Uttara Finance and Investments Limited. & -0.00008 & -0.00487 & 0.40203 & -0.01211 \\
\hline 96 & Jamuna Bank Ltd. & 0.00131 & -0.00348 & 0.28406 & -0.01225 \\
\hline 97 & Fu Wang Food Ltd. & 0.00218 & -0.00261 & 0.20425 & -0.01277 \\
\hline 98 & Uttara Bank Ltd. & 0.00001 & -0.00477 & 0.32736 & -0.01459 \\
\hline 99 & Aftab Automobiles Limited & 0.00066 & -0.00413 & 0.28280 & -0.01459 \\
\hline 100 & Fu-Wang Ceramic Industries Ltd. & 0.00094 & -0.00385 & 0.25127 & -0.01531 \\
\hline 101 & Summit Power Ltd. & -0.00089 & -0.00567 & 0.36483 & -0.01554 \\
\hline 102 & Premier Bank Ltd. & 0.00008 & -0.00470 & 0.27575 & -0.01705 \\
\hline 103 & Islami Bank Bd Ltd & 0.00209 & -0.00270 & 0.15359 & -0.01757 \\
\hline 104 & Dhaka Bank Ltd. & -0.00096 & -0.00575 & 0.32680 & -0.01759 \\
\hline 105 & Deshbandhu Polymer Limited & 0.00194 & -0.00284 & 0.16092 & -0.01766 \\
\hline 106 & Green Delta Insurance Company Ltd. & 0.00062 & -0.00416 & 0.22480 & -0.01851 \\
\hline 107 & Eastern Insurance Co. Ltd. & -0.00274 & -0.00753 & 0.39755 & -0.01893 \\
\hline 108 & First Security Islami Bank Ltd. & -0.00085 & -0.00564 & 0.29198 & -0.01931 \\
\hline 109 & Peoples Insurance Company Ltd. & -0.00215 & -0.00694 & 0.35636 & -0.01947 \\
\hline 110 & Pubali Bank Ltd. & -0.00084 & -0.00562 & 0.27022 & -0.02080 \\
\hline 111 & Union Capital Ltd. & 0.00067 & -0.00412 & 0.19313 & -0.02133 \\
\hline 112 & Standard Bank Ltd. & -0.00235 & -0.00713 & 0.32447 & -0.02199 \\
\hline 113 & Asia Pacific General Insurance Co. Ltd. & -0.00219 & -0.00698 & 0.31658 & -0.02204 \\
\hline 114 & United Finance Limited & -0.00221 & -0.00700 & 0.31180 & -0.02244 \\
\hline 115 & Fareast Islami Life Insurance Co. Ltd. & -0.00355 & -0.00834 & 0.36616 & -0.02277 \\
\hline 116 & United Insurance Company Ltd. & -0.00136 & -0.00615 & 0.26563 & -0.02314 \\
\hline 117 & Rupali Bank Ltd. & 0.00042 & -0.00436 & 0.18556 & -0.02352 \\
\hline 118 & Export Import (Exim) Bank of Bangladesh Ltd. & -0.00260 & -0.00739 & 0.31399 & -0.02352 \\
\hline 119 & Bangladesh General Insurance Company Ltd. & -0.00183 & -0.00661 & 0.27374 & -0.02416 \\
\hline 120 & Titas Gas Trans. \& Dist. Co. Ltd. & -0.00547 & -0.01026 & 0.41024 & -0.02500 \\
\hline 121 & S. Alam Cold Rolled Steels Ltd. & -0.00368 & -0.00846 & 0.33294 & -0.02542 \\
\hline 122 & Rangpur Dairy \& Food Products Limited & -0.00021 & -0.00500 & 0.19446 & -0.02571 \\
\hline 123 & Saiham Textile Mills Ltd. & -0.00421 & -0.00900 & 0.34376 & -0.02618 \\
\hline 124 & Mercantile Insurance Co. Ltd. & -0.00224 & -0.00702 & 0.26278 & -0.02673 \\
\hline
\end{tabular}


JEMA: Jurnal Ilmiah Bidang Akuntansi dan Manajemen, Vol. 16 No. 1 (2019)

http://riset.unisma.ac.id/index.php/jema (e-ISSN : 2597-4071)

\begin{tabular}{|c|c|c|c|c|c|}
\hline $\mathbf{N}$ & $\mathbf{O}$ & $\mathbf{P}$ & $\mathbf{Q}$ & $\mathbf{R}$ & $\mathbf{S}$ \\
\hline 125 & Reliance Insurance Ltd. & -0.00418 & -0.00897 & 0.33274 & -0.02695 \\
\hline 126 & Padma Islami Life Insurance Limited & -0.00215 & -0.00693 & 0.23507 & -0.02950 \\
\hline 127 & Continental Insurance Ltd. & -0.00123 & -0.00602 & 0.19511 & -0.03084 \\
\hline 128 & GBB Power Limited & -0.00711 & -0.01189 & 0.36546 & -0.03254 \\
\hline 129 & AB Bank Limited & -0.00260 & -0.00738 & 0.22182 & -0.03327 \\
\hline 130 & Asia Insurance Co. Ltd. & -0.00481 & -0.00960 & 0.26595 & -0.03609 \\
\hline 131 & Dhaka Electric Supply Company Ltd. & -0.00548 & -0.01026 & 0.28067 & -0.03656 \\
\hline 132 & Northern General Insurance Co. Ltd. & -0.00475 & -0.00953 & 0.25091 & -0.03798 \\
\hline 133 & Meghna Life Insurance Co. Ltd. & -0.00709 & -0.01188 & 0.30623 & -0.03879 \\
\hline 134 & Agrani Insurance Co Ltd. & -0.00354 & -0.00832 & 0.21098 & -0.03943 \\
\hline 135 & Prime Insurance Company Limited & -0.00360 & -0.00838 & 0.21221 & -0.03950 \\
\hline 136 & Square Textiles Limited & -0.00935 & -0.01414 & 0.35771 & -0.03952 \\
\hline 137 & Karnaphuli Insurance Co. Ltd. & -0.00853 & -0.01331 & 0.33039 & -0.04030 \\
\hline 138 & National Bank Ltd. & -0.00479 & -0.00958 & 0.23006 & -0.04162 \\
\hline 139 & Republic Insurance Company Ltd. & -0.00391 & -0.00870 & 0.20893 & -0.04163 \\
\hline 140 & Sonar Bangla Insurance Ltd. & -0.00769 & -0.01248 & 0.29561 & -0.04220 \\
\hline 141 & Popular Life Insurance Company Ltd. & -0.00241 & -0.00719 & 0.16608 & -0.04330 \\
\hline 142 & IFIC Bank Ltd. & -0.00070 & -0.00548 & 0.12338 & -0.04443 \\
\hline 143 & Provati Insurance Company ltd. & -0.00725 & -0.01204 & 0.26502 & -0.04542 \\
\hline 144 & Envoy Textiles Limited & -0.00498 & -0.00976 & 0.21435 & -0.04555 \\
\hline 145 & Saiham Cotton Mills Limited & -0.00905 & -0.01383 & 0.30217 & -0.04578 \\
\hline 146 & Standard Insurance Ltd. & -0.00292 & -0.00770 & 0.16809 & -0.04583 \\
\hline 147 & Pragati Insurance Ltd. & -0.00832 & -0.01310 & 0.27977 & -0.04684 \\
\hline 148 & City General Insurance Co. Ltd. & -0.00785 & -0.01263 & 0.26965 & -0.04685 \\
\hline 149 & Dhaka Insurance Co. Ltd. & -0.01203 & -0.01681 & 0.34932 & -0.04812 \\
\hline 150 & Prime Bank Ltd. & -0.00472 & -0.00951 & 0.19448 & -0.04888 \\
\hline 151 & Paramount Insurance Co. Ltd. & -0.00236 & -0.00715 & 0.14503 & -0.04929 \\
\hline 152 & Central Insurance Company Limited & -0.00573 & -0.01052 & 0.20969 & -0.05015 \\
\hline 153 & Active Fine Chemicals Ltd. & -0.00861 & -0.01339 & 0.25872 & -0.05176 \\
\hline 154 & Rupali Insurance Company Ltd. & -0.01092 & -0.01571 & 0.29158 & -0.05386 \\
\hline 155 & Eastland Insurance Company Limited & -0.01261 & -0.01739 & 0.31146 & -0.05583 \\
\hline 156 & Prime Islami life Insurance Ltd. & -0.00410 & -0.00889 & 0.15289 & -0.05812 \\
\hline 157 & Phoenix Insurance Company Ltd. & -0.00962 & -0.01441 & 0.23969 & -0.06011 \\
\hline 158 & National Life Insurance Co Ltd & -0.00689 & -0.01168 & 0.18738 & -0.06231 \\
\hline 159 & Takaful Islami Insurance Ltd. & -0.00403 & -0.00882 & 0.12321 & -0.07156 \\
\hline 160 & Alif Manufacturing Company Ltd. & -0.00579 & -0.01057 & 0.13463 & -0.07851 \\
\hline 161 & Keya Cosmetics Ltd. & -0.01192 & -0.01670 & 0.20939 & -0.07978 \\
\hline 162 & Sandhani Life Insurance Ltd & -0.01503 & -0.01981 & 0.24798 & -0.07989 \\
\hline 163 & Rupali Life Insurance Co.Ltd. & -0.01071 & -0.01549 & 0.19293 & -0.08031 \\
\hline 164 & Zahintex Industries Limited & -0.00638 & -0.01116 & 0.13270 & -0.08413 \\
\hline 165 & Pioneer Insurance company Ltd. & -0.01376 & -0.01854 & 0.20022 & -0.09261 \\
\hline 166 & Purabi Gen. Insurance Company Ltd. & -0.01711 & -0.02189 & 0.22962 & -0.09535 \\
\hline 167 & Generation Next Fashions Limited & -0.01481 & -0.01960 & 0.19177 & -0.10218 \\
\hline 168 & National Tea Company Limited & -0.00264 & -0.00742 & 0.06378 & -0.11640 \\
\hline
\end{tabular}


JEMA: Jurnal Ilmiah Bidang Akuntansi dan Manajemen, Vol. 16 No. 1 (2019)

http://riset.unisma.ac.id/index.php/jema (e-ISSN : 2597-4071)

\begin{tabular}{|c|l|c|c|c|c|}
\hline $\mathbf{N}$ & \multicolumn{1}{|c|}{$\mathbf{O}$} & $\mathbf{P}$ & $\mathbf{Q}$ & $\mathbf{R}$ & $\mathbf{S}$ \\
\hline $\mathbf{1 6 9}$ & R.N. Spinning Mills Ltd. & -0.00971 & -0.01449 & 0.10019 & -0.14467 \\
\hline $\mathbf{1 7 0}$ & Delta Spinners Ltd. & -0.01595 & -0.02073 & 0.14202 & -0.14599 \\
\hline $\mathbf{1 7 1}$ & Delta Life Insurance Co. Ltd & -0.01578 & -0.02056 & 0.12120 & -0.16967 \\
\hline $\mathbf{1 7 2}$ & Gemini Sea Food Ltd. & 0.03379 & 0.02900 & -0.04778 & -0.60706 \\
\hline $\mathbf{1 7 3}$ & Monno Jute Stafflers Ltd. & 0.03474 & 0.02995 & -0.04531 & -0.66110 \\
\hline $\mathbf{1 7 4}$ & Anwar Galvanizing Ltd. & 0.03342 & 0.02863 & -0.02251 & -1.27203 \\
\hline $\mathbf{1 7 5}$ & Stylecraft Limited & 0.02568 & 0.02090 & -0.01040 & -2.00855 \\
\hline $\mathbf{1 7 6}$ & Eastern Lubricants Ltd. & 0.04159 & 0.03680 & -0.01710 & -2.15210 \\
\hline $\mathbf{1 7 7}$ & Desh Garments Ltd. & 0.05439 & 0.04960 & -0.01552 & -3.19625 \\
\hline $\mathbf{1 7 8}$ & Northern Jute Manufacturing Co. Ltd. & 0.08227 & 0.07749 & -0.00611 & -12.69015 \\
\hline
\end{tabular}

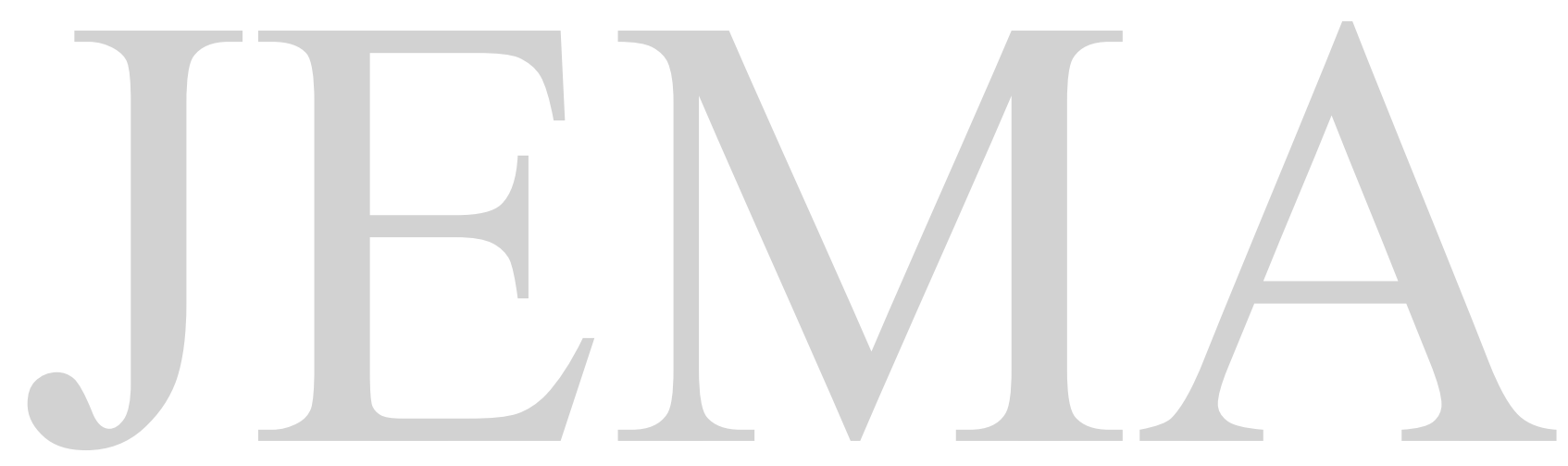


JEMA: Jurnal Ilmiah Bidang Akuntansi dan Manajemen, Vol. 16 No. 1 (2019)

http://riset.unisma.ac.id/index.php/jema (e-ISSN : 2597-4071)

\section{Appendix-D:}

Evaluation of Portfolio Performance with

Code A as Stock Number

Code $\mathrm{N}$ as Rank

\begin{tabular}{|c|c|c|c|c|c|c|c|c|}
\hline $\mathbf{N}$ & $\mathbf{A}$ & $\boldsymbol{\beta}_{i}$ & $X_{i}$ & $\boldsymbol{X}_{i} \boldsymbol{\beta}_{i}$ & $\alpha_{i}$ & $X_{i} \alpha_{i}$ & $\sigma_{e i}^{2}$ & $X_{i}^{2} \sigma_{e i}^{2}$ \\
\hline 1 & 49 & 0.00714 & 0.02324 & 0.00017 & 0.04887 & 0.001136 & 0.04320 & 0.000023336 \\
\hline 2 & 134 & 0.00902 & 0.00971 & 0.00009 & 0.04277 & 0.000415 & 0.08907 & 0.000008395 \\
\hline 3 & 130 & 0.03157 & 0.01059 & 0.00033 & 0.04012 & 0.000425 & 0.07562 & 0.000008480 \\
\hline 4 & 107 & 0.01278 & 0.02381 & 0.00030 & 0.01749 & 0.000416 & 0.01209 & 0.000006850 \\
\hline 5 & 109 & 0.02627 & 0.02353 & 0.00062 & 0.02660 & 0.000626 & 0.02097 & 0.000011613 \\
\hline 6 & 135 & 0.04893 & 0.02354 & 0.00115 & 0.03522 & 0.000829 & 0.02916 & 0.000016157 \\
\hline 7 & 82 & 0.03196 & 0.01415 & 0.00045 & 0.02298 & 0.000325 & 0.02898 & 0.000005800 \\
\hline 8 & 106 & 0.05015 & 0.04996 & 0.00251 & 0.02580 & 0.001289 & 0.00944 & 0.000023554 \\
\hline 9 & 44 & 0.06957 & 0.03657 & 0.00254 & 0.03117 & 0.001140 & 0.01616 & 0.000021614 \\
\hline 10 & 61 & 0.06771 & 0.08153 & 0.00552 & 0.02508 & 0.002045 & 0.00555 & 0.000036880 \\
\hline 11 & 100 & 0.04265 & 0.02110 & 0.00090 & 0.01553 & 0.000328 & 0.01131 & 0.000005034 \\
\hline 12 & 114 & 0.08022 & 0.03759 & 0.00302 & 0.02084 & 0.000783 & 0.00941 & 0.000013300 \\
\hline 13 & 50 & 0.12802 & 0.02147 & 0.00275 & 0.02992 & 0.000642 & 0.02578 & 0.000011881 \\
\hline 14 & 84 & 0.09635 & 0.01364 & 0.00131 & 0.02295 & 0.000313 & 0.02929 & 0.000005449 \\
\hline 15 & 108 & 0.09345 & 0.02780 & 0.00260 & 0.02234 & 0.000621 & 0.01388 & 0.000010731 \\
\hline 16 & 81 & 0.08073 & 0.02025 & 0.00163 & 0.01664 & 0.000337 & 0.01274 & 0.000005226 \\
\hline 17 & 60 & 0.11994 & 0.02352 & 0.00282 & 0.02229 & 0.000524 & 0.01620 & 0.000008957 \\
\hline 18 & 128 & 0.09811 & 0.01979 & 0.00194 & 0.01745 & 0.000345 & 0.01383 & 0.000005415 \\
\hline 19 & 59 & 0.13604 & 0.03033 & 0.00413 & 0.02113 & 0.000641 & 0.01160 & 0.000010675 \\
\hline 20 & 102 & 0.13605 & 0.03983 & 0.00542 & 0.02034 & 0.000810 & 0.00838 & 0.000013296 \\
\hline 21 & 125 & 0.08163 & 0.00804 & 0.00066 & 0.01391 & 0.000112 & 0.02434 & 0.000001573 \\
\hline 22 & 103 & 0.15302 & 0.02986 & 0.00457 & 0.02173 & 0.000649 & 0.01216 & 0.000010840 \\
\hline 23 & 90 & 0.07836 & 0.01040 & 0.00082 & 0.01246 & 0.000130 & 0.01567 & 0.000001696 \\
\hline 24 & 113 & 0.17129 & 0.01600 & 0.00274 & 0.02092 & 0.000335 & 0.02136 & 0.000005468 \\
\hline 25 & 104 & 0.08427 & 0.01872 & 0.00158 & 0.01257 & 0.000235 & 0.00879 & 0.000003081 \\
\hline 26 & 105 & 0.13937 & 0.02713 & 0.00378 & 0.01688 & 0.000458 & 0.00938 & 0.000006904 \\
\hline 27 & 64 & 0.10499 & 0.01739 & 0.00183 & 0.01347 & 0.000234 & 0.01047 & 0.000003165 \\
\hline 28 & 48 & 0.16512 & 0.01397 & 0.00231 & 0.01799 & 0.000251 & 0.01975 & 0.000003856 \\
\hline 29 & 87 & 0.14013 & 0.01813 & 0.00254 & 0.01531 & 0.000278 & 0.01206 & 0.000003962 \\
\hline 30 & 25 & 0.21499 & 0.02998 & 0.00645 & 0.01884 & 0.000565 & 0.00959 & 0.000008624 \\
\hline 31 & 123 & 0.17688 & 0.01267 & 0.00224 & 0.01503 & 0.000190 & 0.01631 & 0.000002616 \\
\hline 32 & 36 & 0.22657 & 0.01991 & 0.00451 & 0.01754 & 0.000349 & 0.01287 & 0.000005099 \\
\hline 33 & 67 & 0.20492 & 0.02820 & 0.00578 & 0.01606 & 0.000453 & 0.00800 & 0.000006364 \\
\hline 34 & 54 & 0.18475 & 0.02063 & 0.00381 & 0.01485 & 0.000306 & 0.00976 & 0.000004151 \\
\hline 35 & 52 & 0.18526 & 0.02981 & 0.00552 & 0.01400 & 0.000417 & 0.00610 & 0.000005417 \\
\hline 36 & 43 & 0.16122 & 0.01092 & 0.00176 & 0.01195 & 0.000131 & 0.01271 & 0.000001516 \\
\hline 37 & 131 & 0.22622 & 0.01366 & 0.00309 & 0.01481 & 0.000202 & 0.01421 & 0.000002651 \\
\hline
\end{tabular}


JEMA: Jurnal Ilmiah Bidang Akuntansi dan Manajemen, Vol. 16 No. 1 (2019) http://riset.unisma.ac.id/index.php/jema (e-ISSN : 2597-4071)

\begin{tabular}{|c|c|c|c|c|c|c|c|c|}
\hline $\mathbf{N}$ & $\mathbf{A}$ & $\boldsymbol{\beta}_{i}$ & $X_{i}$ & $\boldsymbol{X}_{i} \boldsymbol{\beta}_{i}$ & $\alpha_{i}$ & $X_{i} \alpha_{i}$ & $\sigma_{e i}^{2}$ & $X_{i}^{2} \sigma_{e i}^{2}$ \\
\hline 38 & 118 & 0.15249 & 0.00455 & 0.00069 & 0.01149 & 0.000052 & 0.02848 & 0.000000590 \\
\hline 39 & 132 & 0.22110 & 0.03333 & 0.00737 & 0.01425 & 0.000475 & 0.00546 & 0.000006065 \\
\hline 40 & 28 & 0.22960 & 0.01094 & 0.00251 & 0.01301 & 0.000142 & 0.01393 & 0.000001668 \\
\hline 41 & 133 & 0.20568 & 0.00656 & 0.00135 & 0.00935 & 0.000061 & 0.01109 & 0.000000478 \\
\hline 42 & 116 & 0.13350 & 0.00486 & 0.00065 & 0.00768 & 0.000037 & 0.00941 & 0.000000222 \\
\hline 43 & 101 & 0.30569 & 0.01219 & 0.00373 & 0.01126 & 0.000137 & 0.00829 & 0.000001231 \\
\hline 44 & 68 & 0.20622 & 0.00414 & 0.00085 & 0.00888 & 0.000037 & 0.01495 & 0.000000256 \\
\hline 45 & 120 & 0.22901 & 0.00687 & 0.00157 & 0.00904 & 0.000062 & 0.00903 & 0.000000426 \\
\hline 46 & 18 & 0.26881 & 0.00812 & 0.00218 & 0.00940 & 0.000076 & 0.00790 & 0.000000521 \\
\hline 47 & 2 & 0.28493 & 0.00475 & 0.00135 & 0.00918 & 0.000044 & 0.01197 & 0.000000270 \\
\hline 48 & 110 & 0.17229 & 0.00309 & 0.00053 & 0.00743 & 0.000023 & 0.01102 & 0.000000105 \\
\hline 49 & 111 & 0.31474 & 0.01643 & 0.00517 & 0.00953 & 0.000157 & 0.00366 & 0.000000987 \\
\hline 50 & 121 & 0.31933 & 0.00400 & 0.00128 & 0.00883 & 0.000035 & 0.01084 & 0.000000173 \\
\hline 51 & 119 & 0.09248 & 0.00025 & 0.00002 & 0.00594 & 0.000001 & 0.04852 & 0.000000003 \\
\hline 52 & 46 & 0.22916 & 0.00135 & 0.00031 & 0.00716 & 0.000010 & 0.01421 & 0.000000026 \\
\hline 53 & 91 & 0.17462 & 0.00062 & 0.00011 & 0.00643 & 0.000004 & 0.01752 & 0.000000007 \\
\hline 54 & 78 & 0.24299 & 0.00060 & 0.00015 & 0.00665 & 0.000004 & 0.00907 & 0.000000003 \\
\hline & & & $\boldsymbol{\beta}_{p}=$ & 003 & & 0.02 & $\sum_{\substack{i=1 \\
=}}^{N} X_{i}^{2} \sigma_{e i}^{2}$ & 0.000342655 \\
\hline
\end{tabular}

